\title{
Application of Mineral Sorbents for Removal of Petroleum Substances: A Review
}

\author{
Lidia Bandura ${ }^{1, *}$, Agnieszka Woszuk ${ }^{2}$, Dorota Kołodyńska ${ }^{3}$ and Wojciech Franus ${ }^{1}$ \\ 1 Department of Geotechnical Science, Faculty of Civil Engineering and Architecture, \\ Lublin University of Technology, Nadbystrzycka 40, 20-618 Lublin, Poland; w.franus@pollub.pl \\ 2 Department of Roads and Bridges, Faculty of Civil Engineering and Architecture, \\ Lublin University of Technology, Nadbystrzycka 40, 20-618 Lublin, Poland; a.woszuk@pollub.pl \\ 3 Department of Inorganic Chemistry, Faculty of Chemistry, Maria Curie-Skłodowska University, \\ Maria Curie-Skłodowska Sq.2, 20-031 Lublin, Poland; d.kolodynska@poczta.umcs.lublin.pl \\ * Correspondence: 1.bandura@pollub.pl; Tel.: +48-509-381-660
}

Academic Editor: Annalisa Martucci

Received: 15 December 2016; Accepted: 4 March 2017; Published: 8 March 2017

\begin{abstract}
Environmental pollution with petroleum products has become a major problem worldwide, and is a consequence of industrial growth. The development of sustainable methods for the removal of petroleum substances and their derivatives from aquatic and terrestrial environments and from air has therefore become extremely important today. Advanced technologies and materials dedicated to this purpose are relatively expensive; sorption methods involving mineral sorbents are therefore popular and are widely described in the scientific literature. Mineral materials are easily available, low-cost, universal adsorbents and have a number of properties that make them suitable for the removal of petroleum substances. This review describes recent works on the use of natural, synthetic and modified mineral adsorbents for the removal of petroleum substances and their derivatives from roads, water and air.
\end{abstract}

Keywords: petroleum substances; oils; BTEX; sorption; removal; mineral adsorbents

\section{Introduction}

In the modern context of advanced and developing industrialization, petroleum products and their derivatives constitute one of the major sources of environmental pollution. During the extraction, transport, distribution and storage of crude oil and its products, these may be released into the environment in an uncontrolled manner, causing pollution of the atmosphere, lithosphere, hydrosphere and biosphere [1-6]. Due to the extent of impact and the adverse effect of oil derivatives on both the inanimate and animate environment, and the limits imposed on their emissions and permissible concentrations in soils and water, the search for effective methods and new materials for the removal of such substances from contaminated sites is extremely important.

Environmental pollution caused by petroleum substances can be divided into four groups, according to location:

- atmospheric pollution caused by the evaporation of volatile components of petroleum products;

- pollution of soils;

- pollution of aquatic systems;

- environmental pollution caused by land-based spills of petroleum products.

For each of these groups, it is important to choose appropriate methods for the removal of undesirable organic substances in the most efficient way. 
A number of mechanical, biological, chemical and adsorption methods are currently used to remove oil spills from water media and paved roads, and to remove volatile hydrocarbons (Figure 1) [7-14].

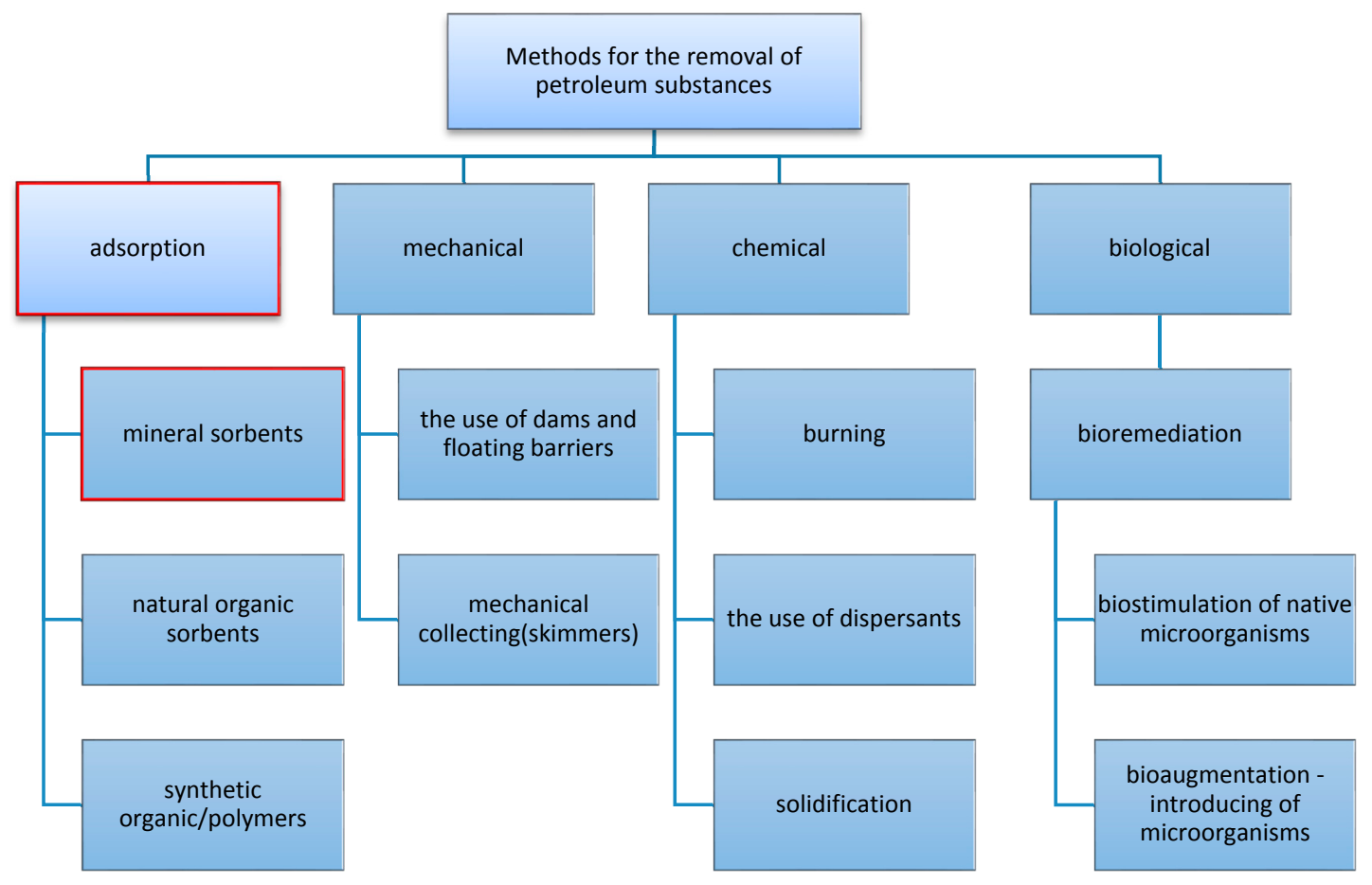

Figure 1. Methods used for the petroleum substance removal.

Solutions applied to volatile organic compounds are primarily aimed at monitoring and reducing their emissions using destructive methods and recovery techniques [15]. The most popular of these are adsorption techniques involving various kinds of adsorbents.

Usually, during rescue operations on waters, more than one method is applied. Comprehensive rescue operations are aimed at efficient removal of oil spills from the water surface and the coastal zones and at preventing further migration of these contaminants. The different cleanup techniques are discussed as follows [16]:

In situ burning is performed as soon as possible after the spill, before the oil stain will begin to evaporate volatile components and disperse. Usually, burning is used at large water surfaces (seas and oceans) but also on land. To perform the burning process effectively the oil spill should be fresh, contain volatile components, and the thickness of the oil layer should be at least $2-3 \mathrm{~mm}$. In addition, the water surface cannot be rough, and the location of burning should be safely away from the residential areas, flammable objects, the coasts, living organisms habitats, etc. Such conditions occur in Arctic areas, since low temperatures limit the movement of water, the dispersion of stains, and evaporation of volatile components [17]. The main advantages of in situ burning are: low costs, high removal efficiency in a relatively short time (100-300 tons per hour). A major drawbacks are the atmospheric emissions of toxic combustion products $\left(\mathrm{CO}, \mathrm{SO}_{2}\right.$, polycyclic aromatic hydrocarbons-PAHs) and the threat of the environment.

Dispersive method involves the removal of residual oil film with the use of surface-active agents (surfactants). Due to an amphiphilic character, they reduce the interfacial tension between oil and water causing dispersion and oil dilution. Thus, further process of natural biodegradation of petroleum compounds is facilitated and the subsequent removal by mechanical, biological or sorption means is easier and more effective $[18,19]$. Due to toxicity the usage of dispersants in some countries is limited (UK, USA). Dispersion method is efficient in the removal of large scale oil spills (it is possible to spray 
dispersants from a helicopter). They are not recommended in the case of heavy, high viscosity oils or in cold, calm water. Surfactants are also used in cleaning soils from petroleum derivatives [20].

Solidifiers are generally dry, granular, hydrophobic organic polymers that react with oil to form a monolithic solid that floats on water [21,22]. The formed solid can be easily removed from the water surface. The effectiveness of solidification depends on the ambient temperature, the type and chemical composition of the oil (solidifier can bind only one type of petroleum substance) which may limit their application. Furthermore, it is recommended to use large amounts of the material $(16 \%-200 \%$ by weight $)$ in relation to the weight of oil spill [23]. Few recent studies in this area indicate that solidification is possible only to local impurities of small range. Mixing solidifiers with the oil is difficult, solidifiers may exhibit toxic properties, there is also a problem with formed solid waste disposal. Sustainable methods for recycling of spent solidifiers have not yet been developed [24].

Mechanical methods belong to the more expensive solutions because they often require the use of specialized equipment. However, they are far less harmful to the environment than chemical methods. These include the application of booms, skimmers, floating dams and barriers in order to limit further spread of oil and to collect it mechanically from the water surface $[10,25]$. Mechanical methods are only effective in case of stagnant water and calm seas, with little wind. The structural designs of skimmers have a great impact on their efficiency. Skimmers allow for the recovery of oil but there exists a risk of oil leakage.

Biological methods are usually applied at the final stage of the purification operations in the aquatic environments or in case of increased acceptable level of pollution in the waters. Their aim is to purify water using microorganisms that are able to decompose petroleum substances and restore the biological balance of aquatic ecosystems. Biological methods are also dedicated to soils polluted with oil derivatives. To this end, strains of native microorganisms are often augmented which seems to be the most efficient in hydrocarbons decomposition in particular localization. For an extensive overview of the topic, readers are sent to the papers: [26-31].

The described methods were applied during the main environmental disasters involving oil spillages from: Liberian tanker at Chedabucto Bay (1971), Exxon Valdez tanker in Prince Williams Sound Alaska (1989), Deepwater Horizon/BP oil rig explosion in Gulf of Mexico (2010). In addition to them, various types of adsorbents were also used.

Sorption methods involve the use of adsorbents which are porous solids with developed specific surface area, capable of binding molecules (from the liquid or gaseous phase) on its surface. Thus, these materials have a wide range of applications, especially in various types of purification technologies. Adsorbents are used for petroleum derivatives removal from coastal areas, waters, paved roads, exhaust gases and vapors. Generally, sorption methods are considered as most effective, inexpensive, available, resistant for atmospheric conditions, easy and safe. In chemical rescue, adsorbents are commonly used to immobilize and remove spills of hazardous liquids from water or paved surfaces. They are also used in situations where it is necessary to remove residual contaminants remaining in the environment after mechanical oil collection, as well as a barrier to prevent the further spread of dangerous liquids (a protective embankment). In most cases, they can be recycled or adsorbed substance can be recovered from them.

The appropriate adsorbent should be chosen depending on the location of the accident and the type and quantity of spilled petroleum substance. In the selection of adsorbent, the following criteria should be taken into account: the sorption capacity of the adsorbent, its ability to immobilize oil, its buoyancy, efficiency, availability and biodegradability, possibility of recycling and/or reuse, environmental impact, price, non-flammability and resistance to chemicals and environmental conditions [8].

Al-Majed et al. [16] have proposed a sustainable pathway for methods of oil spills control. It involves eliminating or reducing chemical methods which are dangerous for the environment through replacing them with most eco-friendly techniques such as mechanical methods and adsorbents. 
The aim of this paper is to present the potential application of natural minerals and synthetic zeolites as the adsorbents for the removal of petroleum substances. Crude oil and petroleum products belong to hazardous environmental pollutants. Because of the extend of impact and adverse effect of oil derivatives on the inanimate and animate environment, it is extremely important to seek effective methods and materials for the removal of such substances from contaminated areas. What is more, proposed solutions should follow the principles of sustainable development which means that the adsorbents have to be easy-available, inexpensive, recyclable or easy to recover, and non-toxic. Mineral adsorbents meet this criteria to a large extent. Recently, numerous research articles on mineral sorbents have been published, in terms of their usage in the removal of petroleum products and the oil spills cleanup. This review summarizes the current results (from the years 2010-2016) on mineral materials and synthetic zeolites that have been used in their raw form and/or after thermal and chemical modifications in the sorption of oils and petroleum compounds from roads, waters and gases.

\section{Adsorbents in the Petroleum Spills Cleanup}

According to Adebajo et al. [32], adsorbents used in the removal of oil spills can be divided into three main groups, depending on the source of origin:

(1) inorganic mineral sorbents;

(2) natural organic sorbents;

(3) synthetic organic sorbents (synthetic polymers).

Mineral adsorbents represent a very large group; these are commonly used as they have a number of advantages such as non-flammability, chemical inertness, relatively low cost and easy availability. These are also known as sinking sorbents, and they are highly dense, fine-grained materials—natural or processed-used to sink floating oil. They can be considered as a group of universal adsorbents. Most mineral adsorbents are raw materials of natural origin which are used in a powder or granular form. Their particle size may range from several $\mathrm{nm}$ to several $\mathrm{mm}$ (not more than $3 \mathrm{~mm}$ ). Mineral adsorbents are generally non-combustible and resistant to acids and bases. Usually, their sorption capacity towards petroleum derivatives is in the range $0.20-0.50 \mathrm{~g} / \mathrm{g}$, and their bulk density is $0.45-0.90 \mathrm{~kg} / \mathrm{dm}^{3}$ [33]. Their primary disadvantage is a risk of dust formation during application in open spaces, and respiratory protective equipment and eye protection are therefore required when using certain powder sorbents. Mineral sorbents are poured onto a (land-based) oil spill, spread onto the surface mechanically (using a brush), allowed to absorb the substance, and are then collected together with the absorbed substance and transferred for recycling. They are not generally preferred for the removal of oil spills from water surfaces because of their low buoyancy, and low oil absorbability comparable to polymers or natural organic sorbents [34]. However, their modification with organic compounds are reported as suitable for water media.

Natural organic adsorbents used in chemical rescue include peat, needle-cover, moss, dry leaves, straw, sawdust, bark and wood waste, cellulose from paper and cotton products, linen materials, cotton and hemp [33]. The literature also describes other sorbents of natural origin from agricultural and/or processing wastes, such as rice husk, various types of plant shells and plant waste, kapok and many others [34-38]. Natural organic adsorbents are considered to be effective, inexpensive (although this is not universally true), easy available and environmentally friendly. They are biodegradable and flammable, and thus are easy to utilize. However, their low bulk density and lightness may cause an impediment in open spaces, and their poor buoyancy limits their use in an aqueous environment. It is impossible to use them in the case of fire. Of the natural organic adsorbents, the most efficient are those subjected to special treatment (e.g., thermal), and these exhibit sorption capacity towards oils in the range $0.7-4.0 \mathrm{~g} / \mathrm{g}$; some papers report sorption performance even/much higher that this [32,33].

The group of synthetic polymers includes polypropylene, polyethylene, polyacrylate, polystyrene, and polyurethane, which are used to manufacture special sleeves, mats, cloths, or cushions for the sorption of hazardous liquids. Polymer adsorbents exhibit hydrophobic properties, low bulk density 
$\left(0.10-0.45 \mathrm{~kg} / \mathrm{dm}^{3}\right)$, and large sorption capacity with respect to petroleum derivatives. Depending on the type of material, the sorption capacity ranging from few to several tens $\mathrm{g} / \mathrm{g}$, and some studies indicate that the capacity can exceed $100 \mathrm{~g} / \mathrm{g}$ [39-41]. Due to their buoyancy and hydrophobicity they are mainly used in aqueous media and very rarely for the removal of oil spills from rigid pavements, since they are often too light and easily blown by the wind. Further disadvantages of these materials are the possibility of returning the absorbed liquid under external forces, non-biodegradability and flame retardant properties. Their utilization also involves the problem of emission of toxic compounds during combustion. Although methods which allow the recovery of the synthetic polymer sorbents after oil sorption, such as centrifugation and pressing, are known, these are very limited due to the destruction of the structure of the sorbent, oxidation or strong contamination.

\subsection{Mineral Adsorbents}

\subsubsection{Zeolites}

Zeolites are aluminosilicates of the alkaline and alkaline earth metals. The main elements of the crystalline framework of zeolites are $\left[\mathrm{SiO}_{4}\right]^{4-}$ and $\left[\mathrm{AlO}_{4}\right]^{3-}$ tetrahedrons connected by oxygen atoms. These tetrahedrons form three-dimensional lattice with free channels of diameter $0.3-3 \mathrm{~nm}$, which gives these minerals a "molecular sieve" character and sorption properties. A negative charge is created as a consequence of the partial replacement of $\mathrm{Si}^{4+}$ ions by $\mathrm{Al}^{3+}$ ions in the zeolites' crystal lattice, which is compensated for by $\mathrm{Ca}^{2+}, \mathrm{Na}^{+}$or $\mathrm{K}^{+}$ions localized in channels where $\mathrm{H}_{2} \mathrm{O}$ molecules are also present. The cations are readily replaced by others from the surrounding solution, thus giving rise to the ion exchange capabilities of zeolites. In addition, surface $\mathrm{OH}$ groups provide these minerals with acid and sorption properties. From the perspective of their origin, zeolites can be divided into natural (created/formed as a result of geological processes occurring in nature) and synthetic. The synthetic zeolites are usually obtained from the chemical reaction between sodium silicate, $\mathrm{Na}_{2} \mathrm{SiO}_{3}$, and sodium aluminate, $\mathrm{NaAlO}_{2}$, under varying conditions of temperature, pressure and reaction time. In addition to pure chemical reagents, raw materials such as fly ash, perlite, clay minerals and obsidian can be used for the synthesis of zeolites [42-46].

\subsubsection{Clay Minerals}

Clay minerals cover several groups of hydrous aluminium phyllosilicates. They form in sediments, soils and as the result of the diagenetic and hydrothermal alteration of rocks. Their foundation is formed from $\left[\mathrm{SiO}_{4}\right]^{4-}$ tetrahedrons, connected at three corners by shared oxygen anions, thus forming the tetrahedral sheet. Divalent or trivalent metal cations (aluminium, magnesium, iron and calcium) are bonded to the tetrahedral sheet, coordinated to one hydroxyl and two oxygen anion groups and surrounded by six oxygens or hydroxyl groups, thus forming the octahedral sheet. Depending on the arrangement of the tetrahedral and octahedral sheets, phyllosilicate ratios of 1:1 (involving units of alternating tetrahedral and octahedral sheets), 2:1 (two tetrahedral and one octahedral sheet) and 2:1:1 (two 2:1 layers with one octahedral sheet between them) can be distinguished $[47,48]$. In the structure of clay minerals the interlayer space is occupied by hydrated cations. The most common representatives of various structures of clay minerals are kaolinite, montmorillonite and sepiolite. Clay minerals exhibit many special properties such as sorption capacity, swelling behaviour, and ion exchange capability which result from their unique structure, the presence of surface $\mathrm{OH}$ groups and weak electrostatic interactions between the layers/sheets and the exchangeable cations.

\subsubsection{Silica Adsorbents}

The group of silica adsorbents includes rocks (siliceous earths, diatomaceous earths, diatomites) and perlite. In terms of their mineral composition, mineraloids dominate this group (opal and chalcedony), with certain amounts of other minerals being present (cristobalite, quartz, clay minerals and carbonates). Opal can occur in a colloidal silica form, with a variable water content (1-21 wt \%) 
which is released in a continuous manner during drying of the mineral. It is an amorphous substance containing a disordered skeleton of $\left[\mathrm{SiO}_{4}\right]^{4-}$ tetrahedrons with $\mathrm{H}_{2} \mathrm{O}$ molecules located in the voids. Opal thus transforms to chalcedony, a semi-crystalline type of quartz. The sorption properties of silica adsorbents result from their significant porosity and the presence of surface hydroxyl groups. These groups are created during the natural formation of opal, and as a result of chemical reactions between the mineral surface and substances present in the environment. Diatomaceous earth and diatomites are formed from the exoskeletons of unicellular algae known as diatoms, which collected at the bottom of water bodies over many millions of years. The exoskeletons of these microorganisms form a unique structure which provides the mineral with a significant contribution of free spaces (between exoskeletons), meso- and macroporosity. Thus, diatomaceous materials are widely used as sorbents of petroleum compounds in the form of oils and vapours of organic compounds [33] including benzene, toluene, ethylbenzene and xylenes (BTEX) [49].

\subsection{Modified Mineral Adsorbents}

All modifications of mineral adsorbents are aimed at improving their sorption parameters towards particular impurities. These modifications generally include a thermal treatment (calcination, expanding) and the functionalization of the mineral's surface with organic compounds.

Calcinated sorbents (e.g., diatomite) exhibit a more developed specific surface area, a higher sorption capacity $(0.50-1.30 \mathrm{~g} / \mathrm{g})$ and slightly lower bulk density $\left(0.45-0.60 \mathrm{~kg} / \mathrm{dm}^{3}\right)$. Examples of expanded adsorbents are perlite and vermiculite; these are characterized by a low bulk density (approximately $0.25 \mathrm{~kg} / \mathrm{dm}^{3}$ ) and good buoyancy, and they can therefore be applied to remove oils from the surface of water [50,51]. Their cost of production is relatively high, and these sorbents tend to return absorbed substances under the influence of external physical and mechanical factors [33].

In recent years, the modification of the surface of minerals with surfactants from the group of quaternary ammonium salts has become a very popular field of research [52-56]. This kind of functionalization changes the character of a mineral materials' surface from hydrophilic to hydrophobic, which usually increases the affinity of the sorbent for organic pollutants. One of the most common organic modifiers is hexadecyltrimethylammonium bromide (HDTMA-Br), typically used to modify the surface of clay minerals. Attempts have been made relatively recently to use these compounds for the modification of natural and synthetic zeolites [57-60]. HDTMA-Br and other salts of this kind can bond to mineral surfaces due to electrostatic forces through exchange with sodium, potassium or calcium cations. These organo-minerals have been studied in terms of the removal of petroleum products in the form of oils, fuels and their derivatives, such as BTEX compounds [52,61-63].

The process of modifying mineral materials with organic compounds increases the cost of the final sorbent, and thus far, this type of organo-mineral sorbents has not found a wide industrial application. It is noteworthy that problems may arise with their further disposal and utilization, as well as the risks related to the toxicity of quaternary ammonium salts [64].

\section{Overview of the Sorption of Petroleum Substances by Mineral Adsorbents}

\subsection{Sorption of Land-Based Oil Spills}

The most popular method of sorption capacity $(S C, g / g)$ determination are weighing the sorbent before and after saturation with the petroleum substance. Sorption capacity is calculated using the equation:

$$
S C=\left(M-M_{0}\right) / M_{0}
$$

where $M$ is the weight of the sorbent after sorption of petroleum product, and $M_{0}$ is weight of the sorbent before sorption. Literature reports different approaches of $S C$ determination via weighing methods. Experimental conditions applied by several researches are described below.

Michel [65] investigated sorption capacity of chalcedonite (Teofilów deposit, Poland), clinoptilolite (Nižný Hrabovec, Zeocem, Slovakia), diatomite (Jawornik deposit, Poland) and quartz sand of two 
different fractions, $0.5-0.8$ and $1.25-2.00 \mathrm{~mm}$, with respect to rape oil and diesel oil. Each of the sorbent $(50 \mathrm{~g})$ was placed in the glass columns $(d=3 \mathrm{~cm})$, then was dropped by the oil until the saturation of whole bed and left to drain. SC was determined by weighing. Bandura et al. [66] used similar procedure to determine SC of clinoptilolite (Sokirnica Mine, Ukraine), diatomite (commercially available sorbent Absodan), and zeolites synthetized from fly ash (Na-P1 and Na-X type) towards diesel and biodiesel oils. Ten grams of the tested sorbent was placed in the glass columns $(d=1 \mathrm{~cm})$, dropped by the oil and left to the bed saturation. Oil excess was slightly removed using pump. The fractions of clinoptilolite and diatomite was $0.5-1.0 \mathrm{~mm}$, whereas zeolites from fly ash was in the powder form.

Muir and Bajda [60] investigated zeolites and organo-zeolites (in the form of powder) in terms of petrol, diesel, engine oil, and used engine oil sorption. Clinoptilolite (Sokirnica Mine) and Na-P1 from fly ash were modified with 8 different surfactants: octadecyltrimethylammonium bromide (ODTMA), hexadecyltrimethylammonium bromide (HDTMA), tetradecyltrimethylammonium bromide (TDTMA), dodecyltrimethylammonium bromide (DDTMA), dioctadecyldimethylammonium bromide (DODDMA), dihexadecyldimethylammonium bromide (DHDDMA), ditetradecyldimethylammonium bromide (DTDDMA) and didodecyldimethylammonium bromide (DDDDMA) which belong to quaternary ammonium salts. Each sample was dropped by the oil gradually, until the point of maximum saturation was achieved. After sorption the unmodified adsorbents have been regenerated by burning with sorbed oil. After cooling, the samples were used as adsorbents again, up to 10 times. It was noted that the sorption efficiency after each sorption-combustion-sorption cycle remained similar to the initial material.

Carmody and Frost [52] used different reference sorbents (mineral and natural organic, commonly available and used for petroleum spills cleanup in a form of granules and/or powders), and organo-clays (montmorillonite and bentonite modified with ODTMA and DDDMA) for sorption of diesel, hydraulic oil and engine oil. The procedure of SC determination was based on the ASTM F726-99: Standard Test Method for Sorbent Performance Of Adsorbents [67]. The sample of a sorbent were placed in a basket and dipped into the oil bath for $15 \mathrm{~min}$. Then, the samples were removed from oil bath, left to drain and weighted.

Zhao et al. [68] used exfoliated vermiculite (EV) and its composite with carbon nanotubes (CNT), e.g., (EV/CNT) for the sorption of diesel and soybean oil and applied similar procedure as Carmody and Frost. Known amount of a sorbent was placed in the glass beaker covered with a metal sieve and was poured with the oil. After $5 \mathrm{~min}$ the beaker was placed upside down and left to drain. The sorbents exhibited irregular elongated forms of particles/grains (EV 1-2 mm; EV/CNT 15-20 mm).

Ankowski [69] investigated the sorption capacity (SC) of commercial sorbents (based on diatomaceous earth and cellulose, provided by Reo Amos, Poland), as well as zeolites from fly ash granulated with the use of bentonite as a binder. The adsorbents were in a granular form and diesel oil was used as a petroleum substance. Measuring cones filled with sorbent were placed in oil bath for $10 \mathrm{~min}$, then collected, drained and weighted.

Alternatively to the weighing, some researchers propose other ways of sorption capacity determination using instrumental methods. These seems to be more convenient in case of powder sorbents, where draining or filtration might be difficult because of the small grain size and the loss of some amount of the material. Sakthviel et al. [56] investigated sorption performance of zeolites and organo-zeolites towards paraffinic process oil. The zeolites was obtained from fly ash, and then functionalized by silanization using propyl-, octyl-, octadecyl-trimethoxysilane and esterification using stearic acid. The sorbents (in a powder form) were mixed with oil in a beaker, stirred for $30 \mathrm{~min}$ and then filtrated under vacuum using Buchner funnel for $10 \mathrm{~min}$. The sorption capacity was determined thermogravimetrically (TGA). Zadaka-Amir et al. [70] and Bandura et al. [71] determined $S C$ of mineral sorbents towards oils using element analysis, e.g., $\mathrm{CHNSO}$ and $\mathrm{CHN}$, respectively, which allows the determination of the carbon content in the samples. Zadaka-Amir et al. used hydraulic oil as a petroleum substance and sepiolite, talc, sand and organo-clays (ODTMA- and 
PTMA (phenyltrimethylammonium bromide)-montmorillonite) as the adsorbents (the adsorbents were powders, apart from sand of grain size $0.8-1.5 \mathrm{~mm}$ ). Bandura et al. investigated SC of clinoptilolite (Sokirnica Mine), diatomite and synthetic zeolites from fly ash (Na-P1, Na-X) (all adsorbents in a powder form) towards diesel, biodiesel and used engine oil. In both papers, proposed experimental conditions reflected the practical use of oil spill sorbents. Oil strains were covered by dry sorbents, then collected after oil sorption and analysed via element analysis in terms of carbon content.

After sorption of petroleum substances by minerals, there occur a problem with generated wastes. Besides thermal regeneration [60], spent sorbents can be used as a substrate for the production of lightweight aggregates [72,73]. The utilization of spent adsorbents in this kind of application provides obtained aggregates with new properties, including higher porosity.

Sorption capacities of mineral and organo-mineral adsorbents in the above mentioned research papers are summarized in Table 1.

Table 1. Sorption capacities $(S C)$ of mineral and organo-mineral adsorbents towards petroleum substances in the form of oils.

\begin{tabular}{|c|c|c|c|}
\hline Sorbent & $S C(\mathrm{~g} / \mathrm{g})$ & $S_{\text {BET }}\left(\mathrm{m}^{2} / \mathrm{g}\right)$ & Source \\
\hline \multicolumn{4}{|l|}{ Zeolites } \\
\hline \multirow[t]{2}{*}{ clinoptilolite (Sokirnica Mine) } & $0.47-0.65$ & 15.88 & {$[60]$} \\
\hline & $0.23-0.38$ & 18.3 & {$[66,71]$} \\
\hline clinoptilolite (Nižný Hrabovec) & $0.19-0.22$ & 29 & [65] \\
\hline $\mathrm{Na}-\mathrm{X}$ & $\begin{array}{l}0.75-0.79 \\
0.91-1.13\end{array}$ & 236.4 & $\begin{array}{l}71] \\
{[66]}\end{array}$ \\
\hline \multirow{3}{*}{$\mathrm{Na}-\mathrm{P} 1$} & $0.86-0.91$ & & [71] \\
\hline & $1.24-1.40$ & 75.6 & [66] \\
\hline & $0.89-1.18$ & 74.9 & [60] \\
\hline zeolites from fly ashes & $0.6-0.9$ & - & [52] \\
\hline zeolites $\mathrm{X}$ & $0.37,1.33$ & 40,404 & [56] \\
\hline \multicolumn{4}{|l|}{ Clay minerals } \\
\hline vermiculite & 1.3 & - & [68] \\
\hline sepiolite & $0.97-1.2$ & 258 & [70] \\
\hline talc & 0.33 & 17 & [70] \\
\hline \multicolumn{4}{|l|}{ Silica rocks } \\
\hline diatomite & $0.17-0.26$ & 30 & [65] \\
\hline chalcedonite & $1.15-1.18$ & 3 & [65] \\
\hline \multirow{3}{*}{ quartz sand } & $0.2-0.3$ & - & [52] \\
\hline & $0.03-0.05$ & - & [65] \\
\hline & 0.17 & - & [70] \\
\hline \multicolumn{4}{|l|}{ Modified minerals/organo-minerals } \\
\hline PTMA-montmorillonite & 0.30 & - & [70] \\
\hline \multirow{2}{*}{ ODTMA-montmorillonite } & 0.37 & - & [70] \\
\hline & $1.2-1.6$ & - & [52] \\
\hline DDDMA-monmorillonite & $3.6-5.2$ & - & [52] \\
\hline DDDMA-bentonite & $2.1-3.5$ & - & [52] \\
\hline zeolite $\mathrm{X}$ modified by propyl-, octyl-, octadecyl-trimethoxysilane and stearic acid & $1.10,1.02,0.86,1.15$ & - & [56] \\
\hline \multirow{2}{*}{$\begin{array}{l}\text { Na-P1 from fly ash and clinoptilolite, both modified with ODTMA, HDTMA, } \\
\text { TDTMA, DDTMA, DODDMA, DHDDMA, DTDDMA, DDDDMA }\end{array}$} & $0.80-1.19$ & $20-64$ & \multirow{2}{*}{ [60] } \\
\hline & $0.36-0.75$ & $4.7-7.0$ & \\
\hline \multicolumn{4}{|l|}{ Commercial mineral adsorbents } \\
\hline sodium aluminosilicate & $0.27-0.43$ & - & [69] \\
\hline Eco-Dry (based on diatomaceous earth) & 1.11 & - & [69] \\
\hline Absodan (diatomite) & $0.80-0.89$ & 24 & [66] \\
\hline & $0.41-0.52$ & 24 & [71] \\
\hline
\end{tabular}


Within the group of zeolitic adsorbents, the highest sorption capacities towards oils were noted for synthetic zeolites obtained from fly ash. Depending on the type of structure and surface area, $S C$ values were in the range $0.6-1.21 \mathrm{~g} / \mathrm{g}$. Lower values of $S C$ were characteristic for zeolites granulated with clay and natural zeolite (clinoptilolite). Within the group of clay adsorbents, higher $S C$ was reported for vermiculite and sepiolite $(0.97-1.3 \mathrm{~g} / \mathrm{g})$. Sorption capacity of sepiolite increased from 0.98 to $1.20 \mathrm{~g} / \mathrm{g}$ after thermal treatment at $300{ }^{\circ} \mathrm{C}$. The authors explain that such improvement might be a result of water loss from the clay which increases the hydrophobicity and affinity for oil. However, thermal treatment at higher temperature $\left(400{ }^{\circ} \mathrm{C}\right)$ slightly decreased $S C$ that is connected with some structural changes of the clay. Talc shows a SC which is clearly lower than the other adsorbents.

Among the silica adsorbents, diatomites exhibit a great diversity in terms of sorption capacities. This may arise from their different particle sizes or from any thermal treatment provided by manufacturer. In addition, diatomites may have a different mineral composition depending on their geological occurrence, which directly influences their sorption properties. Lower sorption parameters are clearly shown by quartz sand; however, due to its widespread availability and very low cost, it is sometimes used for the removal of large oil spills on rigid/paved surfaces.

Grained minerals can be also used for the removal of oil spills from water surfaces, especially near coastal areas. Boglaienko and Tansel [18,74-77] used sand, limestone and clay for the removal of floating oils using a separation technique. The addition of granular particles into the hydrophobic floating phase gradually increases its density. Due to the cohesive forces, the oil phase covers the mineral particles, creating "particle-oil aggregates". As the density of these aggregates reaches a critical point, they separate from the floating organic phase and sink under gravity. In the case of fine quartz sand, the efficiency of removal of oil ( $\% w / w$ ) increased from $31.44 \%$ to $94.35 \%$ with an increase of the amount of granular particles added. The experimental conditions were as follows: $1 \mathrm{~mL}$ crude oil; $100 \mathrm{~mL}$ water; and 0.5, 1.0, 1.5, 2.0, and $3.5 \mathrm{~g}$ of sand. This method allows control over the mobility of oil spills on a water surface, thus reducing the negative impact of petroleum substances on aquatic environments.

The modification of minerals using organic compounds influences their sorption abilities towards oils in various ways, depending on the essential properties of the mineral (its type, surface area, cation exchange capacity CEC, external cation exchange capacity ECEC, etc.), on the properties of the organic compound (the length and multiplicity of an organic chain), and lastly on the process and efficiency of the incorporation of the organic compound into the mineral structure. As a rule, the effect is positive in the case of clay minerals. This is due to the fact that the hydrophilic properties of the surface of a clay mineral change to hydrophobic, and the interlayer spaces within the structure of these minerals increase as a result of organic compound incorporation. On the other hand, in the case of the organo-zeolites investigated, sorption capacity towards oils decreased. This kind of surface modification blocks the pores of zeolites, thus reducing their specific surface area and limiting the access of oil into the pores [56,60].

The recent literature reports that the sorption of petroleum products on mineral adsorbents is affected by factors such as the textural properties of the adsorbent (specific surface area, the contribution and surface of mesopores, mesopore diameters), particle size distribution and bulk density of the adsorbent, and the density and viscosity of an adsorbate [71]. Low bulk density and fine particles favour the formation of capillaries between the material grains, and the contact area between the grains increases with a decrease in their diameter. This leads to an increase in the surface area available for petroleum substances. It can be assumed that the sorption of oil products on porous mineral adsorbents occurs via two mechanisms. The first is associated with the filling of the available pores and capillaries between the sorbent grains using capillary action (mass transfer/flow). Capillary action depends on the effective diameter of the capillary, the surface energy of the interior wall of the capillary, and the viscosity of the oil. The second mechanism is sorption on the outer surface of the sorbent through the formation of an oil layer around the sorbent grains (or optionally around the agglomerates of grains). As in the case of surface adsorption on quartz sand [78], oil can create a uniform layer (film) 
or irregular clusters, depending on the morphology of the surface, its irregularities and roughness, and the properties of the oil. Adsorbents with a well-developed mesoporous structure exhibit relatively higher $S C$ in relation to oils. Micropores present in the structure of minerals are unavailable for large oil particles $[65,71]$. In addition, $S C$ is generally higher for oils of higher density and viscosity $[36,37,79]$. This phenomenon can be explained by the fact that the substances with a higher molecular weight tend to be preferentially adsorbed over those of lower molecular weight [80]. Generally, long-chain hydrocarbons of relatively high molecular weight dominate the chemical composition of higher-density oils (such as spent engine oil).

\subsection{Sorption of Benzene and Its Derivatives Present in Aqueous Solutions by Organo-Mineral Adsorbents}

The issue of the removal of petroleum compounds such as benzene, toluene, ethylbenzene, xylenes (BTEX), other benzene derivatives and volatile organic compounds from water is widely discussed in the literature. Mineral and organo-mineral sorbents are proposed as the alternative to activated carbon or organic polymers. Most studies concern the sorption of BTEX as volatile petroleum derivatives representatives [80-87]. In these papers, different organic compounds have been used for mineral surface functionalization, and the influences of $\mathrm{pH}$, adsorbent dosage and initial concentration on sorption efficiency have been considered, together with the equilibrium and kinetics of sorption. The authors have explored sorption capacities $\left(q_{e}, \mathrm{mg} / \mathrm{g}\right)$ of the adsorbents using standard batch technique and applied popular isotherm and kinetic models for the evaluation of possible sorption mechanisms. The concentrations of organic compounds were determined using chromatography methods such as GC-FID (Gas Chromatography coupled to a Flame Ionization Detector) [49,81,87], GC-MS (Gas Chromatograph coupled to a Mass Spectrometer) [57], HPLC (High Performance Liquid Chromatography) [80]. Table 2 summarizes the results obtained for BTEX and other organic compounds sorption on natural and modified minerals including kinetic and isotherm parameters of the best fitting.

The pseudo-first-order model is described by the equation:

$$
q_{t}=q_{e}\left(1-\mathrm{e}^{-k_{1} t}\right)
$$

where $k_{1}$ is the pseudo-first order rate constant of adsorption $(\mathrm{L} / \mathrm{min}), q_{e}(\mathrm{mg} / \mathrm{g})$ and $q_{t}(\mathrm{mg} / \mathrm{g})$ are the quantities of the adsorbed substance at equilibrium and at time $t$ respectively. This equation is often used to interpret experimental data; however, in practice it shows large deviations in fitting procedures.

The pseudo-second-order model [88] is currently most widely used kinetic equation:

$$
q_{t}=\left(q_{e}^{2} k_{2} t\right) /\left(1-q_{e} k_{2} t\right)
$$

where $k_{2}$ is the pseudo-second-order rate constant of adsorption $(\mathrm{g} /(\mathrm{mg} \cdot \mathrm{min}))$.

The intraparticle diffusion model (Weber and Morris) is expressed by the following equation:

$$
q_{t}=K_{i d} t^{0.5}+C
$$

and assumes that the adsorption varies linearly with the square of the contact time. $K_{i d}$ is the rate constant of intraparticle diffusion $\left(\mathrm{mg} /\left(\mathrm{g} \cdot \mathrm{min}^{0.5}\right)\right), t^{0.5}$ is the square root of the time, and $C$ is the intercept related to the thickness of the boundary layer. 
Table 2. Sorption capacities $\left(q_{e}\right)$ of selected adsorbents towards volatile organic compounds present in aqueous solutions and the most suitable kinetic and isotherm models with parameters.

\begin{tabular}{|c|c|c|c|c|c|c|c|c|c|c|c|}
\hline \multirow[t]{2}{*}{ Sorbent } & \multirow{2}{*}{$\begin{array}{c}S_{\mathrm{BET}} \\
\left(\mathrm{m}^{2} / \mathrm{g}\right)\end{array}$} & \multirow[t]{2}{*}{ Adsorbate } & \multirow{2}{*}{$\begin{array}{c}\mathrm{T} \\
\left({ }^{\circ} \mathrm{C}\right)\end{array}$} & \multirow{2}{*}{$\begin{array}{c}q_{\mathrm{e}} \\
(\mathrm{mg} / \mathrm{g})\end{array}$} & \multirow{2}{*}{$\begin{array}{c}\mathrm{C} \\
(\mathrm{mg} / \mathrm{L})\end{array}$} & \multirow[t]{2}{*}{ Kinetic Model } & \multirow{2}{*}{$\begin{array}{c}k \\
\text { Parameter }\end{array}$} & \multirow{2}{*}{$\begin{array}{l}\text { Isotherm } \\
\text { Model }\end{array}$} & \multicolumn{2}{|c|}{$\begin{array}{l}\text { Isotherm } \\
\text { Constants }\end{array}$} & \multirow[t]{2}{*}{ Source } \\
\hline & & & & & & & & & $K_{f}$ & $1 / n$ & \\
\hline \multirow{6}{*}{ diatomite raw } & \multirow{6}{*}{38.4} & benzene & & 0.10 & 50 & \multirow{6}{*}{$\begin{array}{c}\text { Pseudo-second-order, } \\
k_{2}\left(\mathrm{~g} \cdot(\mathrm{mg} \cdot \mathrm{h})^{-1}\right)\end{array}$} & 3.3263 & \multirow{6}{*}{ Freundlich } & $3.68 \times 10^{-5}$ & 2.47 & \multirow{6}{*}{ [49] } \\
\hline & & toluene & & 0.15 & 50 & & 1.8276 & & $1.92 \times 10^{-3}$ & 1.33 & \\
\hline & & ethylbenzene & & 0.30 & 50 & & 0.9134 & & $4.44 \times 10^{-2}$ & 0.55 & \\
\hline & & p-xylene & 20 & 0.34 & 50 & & 0.9214 & & $6.11 \times 10^{-2}$ & 0.48 & \\
\hline & & $o$-xylene & & 0.20 & 50 & & 0.5226 & & $4.6 \times 10^{-2}$ & 0.46 & \\
\hline & & MTBE & & 0.08 & 100 & & 2.1956 & & $5.92 \times 10^{-10}$ & 4.38 & \\
\hline \multirow{6}{*}{$\begin{array}{l}\text { diatomite } \\
\text { calcinated at } \\
550{ }^{\circ} \mathrm{C}\end{array}$} & \multirow{6}{*}{43.3} & benzene & & 0.06 & 50 & \multirow{6}{*}{$\begin{array}{c}\text { Pseudo-second-order, } \\
k_{2}\left(\mathrm{~g} \cdot(\mathrm{mg} \cdot \mathrm{h})^{-1}\right)\end{array}$} & 18.0996 & \multirow{6}{*}{ Freundlich } & $1.55 \times 10^{-13}$ & 8.13 & \multirow{6}{*}{ [49] } \\
\hline & & toluene & & 0.21 & 50 & & 7.2447 & & $6.61 \times 10^{-12}$ & 7.29 & \\
\hline & & ethylbenzene & & 0.62 & 50 & & 4.7319 & & $7.41 \times 10^{-11}$ & 6.07 & \\
\hline & & p-xylene & 20 & 0.82 & 50 & & 2.1946 & & $2.74 \times 10^{-10}$ & 5.71 & \\
\hline & & $o$-xylene & & 0.64 & 50 & & 2.6614 & & $6.02 \times 10^{-13}$ & 7.25 & \\
\hline & & MTBE & & 0.01 & 100 & & 48.9326 & & $4.36 \times 10^{-11}$ & 4.82 & \\
\hline \multirow{6}{*}{$\begin{array}{c}\text { diatomite } \\
\text { calcinated at } \\
750{ }^{\circ} \mathrm{C}\end{array}$} & \multirow{6}{*}{31.8} & benzene & & 0.21 & 50 & \multirow{6}{*}{$\begin{array}{c}\text { Pseudo-second-order, } \\
k_{2}\left(\mathrm{~g} \cdot(\mathrm{mg} \cdot \mathrm{h})^{-1}\right)\end{array}$} & 0.3069 & \multirow{6}{*}{ Freundlich } & $1.35 \times 10^{-7}$ & 4.45 & \multirow{6}{*}{ [49] } \\
\hline & & toluene & & 0.22 & 50 & & 0.1868 & & $9.82 \times 10^{-9}$ & 5.50 & \\
\hline & & ethylbenzene & 20 & 0.58 & 50 & & 0.0557 & & $1.95 \times 10^{-6}$ & 3.63 & \\
\hline & & $p$-xylene & 20 & 0.75 & 50 & & 0.1581 & & $3.18 \times 10^{-6}$ & 3.46 & \\
\hline & & $o$-xylene & & 0.50 & 50 & & 0.3335 & & $1.02 \times 10^{-9}$ & 5.46 & \\
\hline & & MTBE & & 0.21 & 100 & & 0.4441 & & 48.42 & 1.53 & \\
\hline \multirow{6}{*}{$\begin{array}{c}\text { diatomite } \\
\text { calcinated at } \\
950{ }^{\circ} \mathrm{C}\end{array}$} & \multirow{6}{*}{7.7} & benzene & & 0.10 & \multirow{6}{*}{ - } & \multirow{6}{*}{$\begin{array}{c}\text { Pseudo-second-order, } \\
k_{2}\left(\mathrm{~g} \cdot(\mathrm{mg} \cdot \mathrm{h})^{-1}\right)\end{array}$} & 2.0324 & & & & \\
\hline & & toluene & & 0.11 & & & 0.7896 & & & & \\
\hline & & ethylbenzene & 20 & 0.38 & & & 0.2091 & & - & - & [49] \\
\hline & & p-xylene & 20 & 0.42 & & & 0.5710 & & - & - & [49] \\
\hline & & $o$-xylene & & 0.23 & & & 1.2817 & & & & \\
\hline & & MTBE & & 0.05 & & & 0.0002 & & & & \\
\hline
\end{tabular}


Table 2. Cont

\begin{tabular}{|c|c|c|c|c|c|c|c|c|c|c|c|}
\hline \multirow{2}{*}{ Sorbent } & \multirow{2}{*}{$\begin{array}{c}S_{\text {BET }} \\
\left(\mathrm{m}^{2} / \mathrm{g}\right)\end{array}$} & \multirow{2}{*}{ Adsorbate } & \multirow{2}{*}{$\begin{array}{c}\mathrm{T} \\
\left({ }^{\circ} \mathrm{C}\right)\end{array}$} & \multirow{2}{*}{$q_{\mathrm{e}}(\mathrm{mg} / \mathrm{g})$} & \multirow{2}{*}{$\begin{array}{c}\mathrm{C} \\
(\mathrm{mg} / \mathrm{L})\end{array}$} & \multirow{2}{*}{ Kinetic Model } & \multirow{2}{*}{$\begin{array}{c}k \\
\text { Parameter }\end{array}$} & \multirow{2}{*}{$\begin{array}{l}\text { Isotherm } \\
\text { Model }\end{array}$} & \multicolumn{2}{|c|}{$\begin{array}{l}\text { Isotherm } \\
\text { Constants }\end{array}$} & \multirow{2}{*}{ Source } \\
\hline & & & & & & & & & $K_{f}$ & $1 / n$ & \\
\hline \multirow{7}{*}{$\begin{array}{l}\text { HDTMA } \\
\text { smectite }\end{array}$} & \multirow{6}{*}{61.7} & benzene & & 0.52 & 10.82 & \multirow{6}{*}{$\begin{array}{l}\text { Langmuir-Freundlich, } \\
k_{a} \times 10^{2} \\
{\left[\mathrm{~L}^{\mathrm{n}} /\left(\mathrm{g} \cdot \mathrm{min} \cdot \mathrm{mg}^{\mathrm{n}-1}\right)\right]}\end{array}$} & 5.19 & & \multirow{6}{*}{-} & \multirow{6}{*}{-} & \multirow{6}{*}{ [80] } \\
\hline & & toluene & & 0.69 & 29.06 & & 9.30 & & & & \\
\hline & & ethylbenzene & & 0.72 & 8.58 & & 5.04 & - & & & \\
\hline & & $p$-xylene & 23 & 0.75 & 8.55 & & 6.05 & - & & & \\
\hline & & $m$-xylene & & 0.76 & 8.52 & & 5.97 & & & & \\
\hline & & phenol & & 0.51 & 10.00 & & 0.34 & & & & \\
\hline & & & & & & & & & $K_{f}$ & $1 / n$ & \\
\hline \multirow{4}{*}{$\begin{array}{c}\text { PEG } \\
\text { montmorillonite }\end{array}$} & \multirow{4}{*}{27.8} & benzene & & 3.47 & 37.5 & \multirow{4}{*}{$\begin{array}{l}\text { Pseudo-second-order, } \\
\quad k_{2}\left(\mathrm{~g} \cdot(\mathrm{mg} \cdot \mathrm{h})^{-1}\right)\end{array}$} & 0.264 & \multirow{4}{*}{ Freundlich } & 0.024 & 0.763 & \multirow{4}{*}{ [81] } \\
\hline & & toluene & & 4.18 & 37.5 & & 0.241 & & 0.043 & 0.725 & \\
\hline & & ethylbenzene & 25 & 5.12 & 37.5 & & 0.199 & & 0.027 & 0.637 & \\
\hline & & xylene & & 6.00 & 37.5 & & 0.153 & & 0.016 & 0.719 & \\
\hline \multirow{3}{*}{$\begin{array}{c}\text { HDTMA } \\
\text { clinoptilolite }\end{array}$} & \multirow[b]{3}{*}{-} & benzene & & 0.22 & 9 & \multirow{3}{*}{$\begin{array}{l}\text { Pseudo-second-order, } \\
k_{2}\left(\mathrm{~g} \cdot(\mathrm{mg} \cdot \mathrm{h})^{-1}\right)\end{array}$} & 4.46 & \multirow{3}{*}{-} & \multirow{3}{*}{-} & & \multirow{3}{*}{ [87] } \\
\hline & & toluene & & 0.20 & 9 & & 6.49 & & & & \\
\hline & & ethylbenzene & 20 & 0.16 & 9 & & 5.60 & & & & \\
\hline \multirow{4}{*}{$\begin{array}{c}\text { CPB } \\
\text { clinoptilolite }\end{array}$} & & benzene & & 0.35 & 9 & & 1.94 & & & & \\
\hline & 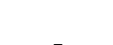 & toluene & & 0.30 & 9 & Pseudo-second-order, & 1.64 & 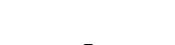 & 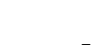 & & \\
\hline & - & ethylbenzene & 20 & 0.27 & 9 & $k_{2}\left(\mathrm{~g} \cdot(\mathrm{mg} \cdot \mathrm{h})^{-1}\right)$ & 1.47 & - & - & & [87] \\
\hline & & xylene & & 0.26 & 9 & & 1.42 & & & & \\
\hline & & benzene & & 1.07 & 9 & & 5.12 & & & & \\
\hline Clinoptilolite & _- & toluene & 20 & 0.83 & 9 & Pseudo-second-order, & 2.87 & _- & _- & & [87] \\
\hline clinoptilonte & & ethylbenzene & 20 & 0.67 & 9 & $k_{2}\left(\mathrm{~g} \cdot(\mathrm{mg} \cdot \mathrm{h})^{-1}\right)$ & 6.46 & & - & & {$[8 /]$} \\
\hline & & xylene & & 0.62 & 9 & & 8.82 & & & & \\
\hline & & benzene & & 1.16 & 9 & & 1.94 & & & & \\
\hline & & toluene & & 0.89 & 9 & Pseudo-second-order, & 4.46 & & & & \\
\hline clinoptilolite & - & ethylbenzene & 20 & 0.73 & 9 & $k_{2}\left(\mathrm{~g} \cdot(\mathrm{mg} \cdot \mathrm{h})^{-1}\right)$ & 7.27 & - & - & & [87] \\
\hline & & xylene & & 0.66 & 9 & & 4.88 & & & & \\
\hline
\end{tabular}


Table 2. Cont

\begin{tabular}{|c|c|c|c|c|c|c|c|c|c|c|c|}
\hline \multirow{2}{*}{ Sorbent } & \multirow{2}{*}{$\begin{array}{c}S_{\mathrm{BET}} \\
\left(\mathrm{m}^{2} / \mathrm{g}\right)\end{array}$} & \multirow[t]{2}{*}{ Adsorbate } & \multirow{2}{*}{$\begin{array}{c}\mathrm{T} \\
\left({ }^{\circ} \mathrm{C}\right)\end{array}$} & \multirow[t]{2}{*}{$q_{\mathrm{e}}(\mathrm{mg} / \mathrm{g})$} & \multirow{2}{*}{$\underset{(\mathrm{mg} / \mathrm{L})}{\mathrm{C}}$} & \multirow[t]{2}{*}{ Kinetic Model } & \multirow{2}{*}{$\begin{array}{c}k \\
\text { Parameter }\end{array}$} & \multirow{2}{*}{$\begin{array}{l}\text { Isotherm } \\
\text { Model }\end{array}$} & \multicolumn{2}{|c|}{$\begin{array}{l}\text { Isotherm } \\
\text { Constants }\end{array}$} & \multirow[t]{2}{*}{ Source } \\
\hline & & & & & & & & & $K_{f}$ & $1 / n$ & \\
\hline \multirow[t]{2}{*}{ Zeolite Y } & \multirow[t]{2}{*}{650.3} & $\begin{array}{c}\text { benzene } \\
\text { toluene } \\
\text { ethylbenzene } \\
o \text {-xylene } \\
m, p \text {-xylene }\end{array}$ & 20 & $\begin{array}{l}0.01 \\
0.10 \\
0.05 \\
0.10 \\
0.02\end{array}$ & $\begin{array}{l}10 \\
10 \\
10 \\
10 \\
10\end{array}$ & $\begin{array}{l}\text { Pseudo-second-order, } \\
\quad k_{2}\left(\mathrm{~g} \cdot(\mathrm{mg} \cdot \mathrm{h})^{-1}\right)\end{array}$ & - & - & - & & [57] \\
\hline & & & & & & & & & $K_{t}$ & $b$ & \\
\hline HDTMA-Y 100 & - & $\begin{array}{c}\text { benzene } \\
\text { toluene } \\
\text { ethylbenzene } \\
o \text {-xylene } \\
m, p \text {-xylene }\end{array}$ & 28 & $\begin{array}{l}12.13 \\
13.75 \\
13.86 \\
13.98 \\
13.98\end{array}$ & $\begin{array}{l}10 \\
10 \\
10 \\
10 \\
10\end{array}$ & $\begin{array}{l}\text { Pseudo-second-order, } \\
\quad k_{2}\left(\mathrm{~g} \cdot(\mathrm{mg} \cdot \mathrm{h})^{-1}\right)\end{array}$ & $\begin{array}{l}7.114 \\
3.825 \\
1.891 \\
1.460 \\
2.092 \\
\end{array}$ & Temkin & $\begin{array}{l}0.463 \\
0.368 \\
5.125 \\
0.869 \\
0.924 \\
\end{array}$ & $\begin{array}{l}2.848 \\
1.362 \\
0.429 \\
0.554 \\
0.694 \\
\end{array}$ & [57] \\
\hline Na-P1 & 88 & $\begin{array}{l}\text { benzene } \\
\text { toluene } \\
p \text {-xylene }\end{array}$ & 20 & $\begin{array}{l}1.38-6.11 \\
1.44-8.64 \\
1.81-11.41\end{array}$ & - & - & - & - & - & & [58] \\
\hline HDTMA-NaP1 & - & $\begin{array}{l}\text { benzene } \\
\text { toluene } \\
p \text {-xylene }\end{array}$ & 20 & $\begin{array}{l}1.36-10.28 \\
1.40-9.99 \\
1.79-11.47\end{array}$ & - & - & - & - & - & & [58] \\
\hline
\end{tabular}


The Langmuir isotherm describes the adsorption at specific homogeneous sites on the adsorbent surface, without significant interaction between the adsorbed species. The Langmuir isotherm is represented by the following equation:

$$
q_{e}=\left(q_{m} K_{L} C_{e}\right) /\left(1+K_{L} C_{e}\right)
$$

where $C_{e}$ is the solute concentration at equilibrium (mg/L), $q_{e}$ is the adsorption capacity at equilibrium $(\mathrm{mg} / \mathrm{g}), K_{L}$ is the Langmuir adsorption constant $(\mathrm{L} / \mathrm{mg})$, and $q_{m}$ is monolayer capacity $(\mathrm{mg} / \mathrm{g})$.

The Freundlich model can be applied to non-ideal systems, including multilayer adsorption processes on heterogeneous surfaces, and is expressed by the following equation:

$$
q_{e}=K_{F} C_{e}^{1 / n}
$$

where $K_{F}\left(\mathrm{mg} \cdot \mathrm{kg}^{-1}(\mathrm{mg} / \mathrm{L})^{n}\right)$ and $1 / n$ are the Freundlich adsorption isotherm constants related to the saturation capacity and intensity of adsorption respectively. Values of $1 / n$ of between 0.1 and 1 indicate favorable adsorption. Higher values of $1 / n$ suggest unfavorable conditions for adsorption and the possibility of competitive adsorption.

The Langmuir-Freundlich model can be described as:

$$
q_{e}=q_{m}\left(K_{a} C_{e}\right)^{n} /\left(K_{a} C_{e}\right)^{n}+1
$$

where: $q_{e}$ is the adsorption capacity, $q_{m}$ is the adsorption capacity of the system $(\mathrm{mg} / \mathrm{g}), C_{e}$ is the aqueous phase concentration at equilibrium $(\mathrm{mg} / \mathrm{L})$, described as previously and $K_{a}$ is the affinity constant for adsorption $\left(\mathrm{L}^{n} / \mathrm{g} \cdot \mathrm{min} \cdot \mathrm{mg}^{n-1}\right), n$ is the index of heterogeneity.

The Temkin isotherm considers the effects of indirect adsorbate-adsorbate interactions and assumes that heats of adsorption will more often decrease than increase with increasing coverage. The equation has the form:

$$
q_{e}=(R T / b) \ln \left(A C_{e}\right)
$$

where $T$ is the absolute temperature $(\mathrm{K}), R$ is the gas constant, $A$ is the Temkin isotherm constant $(\mathrm{L} / \mathrm{g})$, $b$ is the Temkin constant related to the heat of sorption $(\mathrm{kJ} / \mathrm{mol})$.

The detailed description on the experimental conditions connected with the data presented in Table 2 were added below.

Aivalioti et al. [49] studied the sorption of benzene, ethylbenzene, toluene, xylenes and methyl tertiary butyl ether (MTBE) from aqueous solutions on diatomite (Kazani, Northern Greece) [49]. The mineral was milled and the fraction of $64-120 \mu \mathrm{m}$ was chosen for the study. The diatomite was thermally activated at 550, 750 and $950^{\circ} \mathrm{C}$. The sorption kinetic and isotherm experiments was conducted for multi-component solution (a mixture of BTEX and MTBE) at $20^{\circ} \mathrm{C}$. The maximum duration of contact time was 21 days but the time needed to achieve equilibrium state was 10 days. The initial concentration of the multi-component solutions for kinetic and equilibrium studies was around $250 \mathrm{mg} / \mathrm{L}$ of BTEX (50 mg/L of each compound) and $100 \mathrm{mg} / \mathrm{L}$ of MTBE. Kinetic study was performed using diatomite to solution ratio of 1:10, whereas the sorbent to solution ratios in case of equilibrium study were 1:25, 1:15, 1:10, 1:5, 1:4, and 1:3. The sorption of BTEX compounds at equilibrium state was in the range $0.1-0.38 \mathrm{mg} / \mathrm{g}$ for raw diatomite (without thermal activation) and increased to $0.8 \mathrm{mg} / \mathrm{g}$ for diatomite calcinated at $750{ }^{\circ} \mathrm{C}$. The uptake of MTBE was relatively low $(0.01-0.21 \mathrm{mg} / \mathrm{g})$. Calcination provided loss of water and impurities from pores and active sites of the mineral, thus increasing the external surface area available for adsorbate molecules. Based on the correlation coefficients $R^{2}$ values the experimental data fit the pseudo-second order kinetic model and Freundlich isotherm model. The values of Freundlich constant $1 / n$ higher than 1 suggest unfavorable sorption. Sorption capacities followed the order: $p$-xylene $>$ ethyl-benzene $>o$-xylene $>$ toluene $>$ benzene $>$ MTBE resulted from the descending order of hydrophobicity (based on their octanol-water coefficient log values: 3.15, 3.15, 2.77, 2.69, 2.13 and 1.06, respectively), molecular weight, 
and approximately ascending order of water solubility $(198,152,175,515,1700$ and 47,000 mg/L, respectively) [49].

Carvalho et al. [80] used smectite (Paraiba, Brazil) functionalized with HDTMA for the sorption of benzene, toluene, ethylbenzene, $p$-xylene, $m$-xylene and phenol from single-component and multi-component solutions at $23{ }^{\circ} \mathrm{C}$. The influence of $\mathrm{pH}(4,7$ and 9), contact time (time intervals in the range $0.5-240 \mathrm{~min}$ ) and initial concentration of the solution (from 2 to $29 \mathrm{mg} / \mathrm{L}$ at optimal $\mathrm{pH}=9$ and contact time $240 \mathrm{~min}$ ) on sorption efficiency was investigated. The most efficient sorption levels were noted at $\mathrm{pH}=9$. At lower $\mathrm{pH}$ values, the ions $\mathrm{H}^{+}$might coordinate to active sites (surface silanol groups) of the organoclay and block them. For single-component system the removal efficiencies ranged between $55 \%$ and $90 \%$, whereas those for multi-component system were lower (between 30\% and 90\%). Sorption capacity $\left(q_{e}\right)$ towards BTEX was in the range $0.25-0.4 \mathrm{mg} / \mathrm{g}$ for multi-component system (Table 2) and followed the order xylenes $>$ ethylbenzene $>$ toluene $>$ benzene. The adsorption equilibrium was established after $60 \mathrm{~min}$. Authors applied pseudo-first, pseudo-second and Langmuir-Freundlich models for kinetic data interpretation and the best fitting was noted for Langmuir-Freundlich. Analyzing the obtained kinetic parameters they have assumed that: (i) toluene and $p$-xylene exhibit a high adsorption affinity to organoclay surface and high binding energy of adsorption; (ii) phenol and ethylbenzene cover many active sites of organoclay and that they are not selective for one particular active site; (iii) toluene have the highest rate of adsorption, whereas phenol have the slowest rate.

Nourmoradi et al. [81] examined montmorillonite (Laviosa Co., Livorno, Italy) modified with poly ethylene glycol (PEG) in terms of benzene, toluene, ethylbenzene and xylenes sorption from aqueous solution (multi-component). Grain size of the sorbent did not exceed $125 \mu \mathrm{m}$. Loading rates of the surfactant $(0.2-4.00 \mathrm{CEC}$ of the montmorillonite), contact time $(0-24 \mathrm{~h}), \mathrm{pH}$, adsorbate initial concentration $C_{0}(10-200 \mathrm{mg} / \mathrm{L}$ of BTEX mixture) and solution ion strength $(20-100 \mathrm{mg} / \mathrm{L}$ of calcium ions) on the BTEX sorption capacity was investigated at $25^{\circ} \mathrm{C}$. In the studied BTEX solutions $\mathrm{C}_{0}$ of benzene, toluene and xylene (in $\mathrm{mg} / \mathrm{L}$ ) were equal. Also the influence of temperature $\left(10-40{ }^{\circ} \mathrm{C}\right)$ on sorption efficiency was studied. The regeneration of the adsorbent was performed by heating at $150{ }^{\circ} \mathrm{C}$ at 5,10 and $20 \mathrm{~min}$, and the efficiency of sorption for each regeneration cycle was further estimated. The optimal surfactant loading rate was 2.0 CEC which provided the highest BTEX uptake. Higher loading rates resulted in the decrease of BTEX sorption. $\mathrm{pH}$ and ion strength did not influenced significantly the BTEX adsorption. Sorption increased rapidly during the first hour of sorption and the equilibrium was achieved at the contact time of $24 \mathrm{~h}$. The adsorption capacity $\left(q_{\mathrm{e}}\right)$ was in the range $3.47-5.12 \mathrm{mg} / \mathrm{g}$ and followed the order: xylene $>$ ethylbenzene $>$ toluene $>$ benzene. The experimental data were analysed using pseudo-first-order, pseudo-second-order, and intraparticle diffusion kinetic models and Langmuir, Freundlich and D-R isotherm models. The best fitting was obtained for pseudo-second-order model and Freundlich isotherm. Obtained parameters indicate the highest sorption rate for xylenes, and the favorable physical sorption $(1 / n<1)$. The thermodynamic study revealed that the BTEX sorption by PEG-montmorillonite was spontaneous, endothermic and favorable at higher temperatures. Sorption efficiency of regenerated PEG-montmorillonite was $18.14 \%-23.08 \%$ and $51.28 \%-60.70 \%$ of the original material after 5 and 20 min of heating, respectively.

Seifi et al. [87] used clinoptilolite (Miyaneh, Iran) modified with HDTMA and CPB (n-cetyl piridinium bromide) for the sorption of BTEX compounds from multi-component solution. The clinoptilolite was in powder $(590-840 \mu \mathrm{m})$ and granulated forms before modification (the granulation process is described in the paper). The paper presents a comprehensive study of the sorption kinetics. Batch experiments for the single-component systems were carried out at $20{ }^{\circ} \mathrm{C}$ within the contact time range $0.5-72 \mathrm{~h}$. The initial concentration of each compound was $9 \mathrm{mg} / \mathrm{L}$. The optimal time for achieving the equilibrium was $24 \mathrm{~h}$ for natural and $8 \mathrm{~h}$ for granulated adsorbents. Intra-particle diffusion models (Weber and Morris and Vermeulen) and surface reaction models (pseudo-first order, pseudo-second order, and Elovich) were applied for interpretation the experimental data and pseudo-second order model was the most suitable. It was noticed that the intra-particle 
diffusion is prevailing in the first stage of adsorption for a relatively short time. Sorption capacities for organozeolites were in the range $0.15-0.35$ and $0.6-1.2 \mathrm{mg} / \mathrm{g}$ for granulated nano-organozeolites. The sorption capacities followed the order: benzene $>$ toluene $>$ ethylbenzene $>$ xylenes. The adsorbents modified by CPB showed higher adsorption capacity compared to the HDTMA-modified adsorbents.

Vidal et al. [57] used commercial synthetic zeolite $\mathrm{Y}$ and HDMA as a surfactant for zeolite modification. The HDTMA loading level was $0.5,1.0$ and 2.0 of the total CEC of the zeolite Y. The best results were obtained at an HDTMA loading level of 1.0 of the zeolite CEC. Kinetics and isotherm studies for multi-component BTEX solutions were performed at $28^{\circ} \mathrm{C}$. The contact time ranged from $30 \mathrm{~min}$ to $48 \mathrm{~h}$ and the BTEX concentration was $10 \mathrm{mg} / \mathrm{L}$ for each compound. The sorption equilibrium was reached within $6 \mathrm{~h}$. In the isotherm study, BTEX initial concentration for each compound was in the range $2-60 \mathrm{mg} / \mathrm{L}$ and $12-360 \mathrm{mg} / \mathrm{L}$ for multi-component solution. The experimental data was evaluated using pseudo-first, pseudo-second and intraparticle diffusion kinetic models and Langmuir, Freundlich, Redlich-Peterson and Temkin isotherms. Based on the values of correlation coefficients the best fitting was obtained for pseudo-second order model and Temkin isotherm indicating the effects of indirect adsorbate-adsorbate interactions. Adsorption capacity was $12.13 \mathrm{mg} / \mathrm{g}$ for benzene, $13.75 \mathrm{mg} / \mathrm{g}$ for toluene, $13.86 \mathrm{mg} / \mathrm{g}$ for ethylbenzene, $13.98 \mathrm{mg} / \mathrm{g}$ for $o$-xylene, and $13.98 \mathrm{mg} / \mathrm{g}$ for $m$ - and $p$-xylene. Sorption capacity for unmodified zeolite was significantly lower. The adsorption capacities followed the order: $m$-, $p$-xylene $>0$-xylene $>$ ethylbenzene $>$ toluene $>$ benzene, likewise in other papers. Regeneration of the HDTMA-zeolite $\mathrm{Y}$ were performed by heating the sorbent at $100^{\circ} \mathrm{C}$ for $6 \mathrm{~h}$, followed by a new adsorption cycle (up to 5 times). The results have shown that the sorption efficiency was at the same level after 4 cycles of regeneration, except benzene, for which sorption efficiency has been reduced after first regeneration cycle.

Szala et al. [58] used zeolite Na-P1 prepared from fly ash modified with HDTMA using loading levels of $0.2,0.4,0.6,0.8$ and 1.0 of the external cation exchange capacity (ECEC) of Na-P1 for the sorption of benzene, toluene and xylene. Sorption experiments were carried out at room temperature $\left(20^{\circ} \mathrm{C}\right)$ at the initial concentration. Depending on the initial concentration of benzene, toluene and xylene (50,100, $250 \mathrm{mg} / \mathrm{L}$ ), the sorption capacities varied from about 1.38 to $11.47 \mathrm{mg} / \mathrm{g}$. The best adsorption uptake was achieved for HDTMA-Na-P1 with loading level of 1.0 ECEC. The modification improved the sorption capacity of Na-P1 in terms of BTX compounds (benzene, toluene, xylenes) by several per cent.

The sorption selectivity in most studies followed the order xylenes $>$ ethylbenzene $>$ toluene $>$ benzene $[57,80-82]$. The dependency might be explained by molecular weight of the adsorbates, their hydrophobicity, water solubility, the size and geometrical shape of adsorbate particles, and the type of functional groups. Generally, the adsorbates of higher molecular weight and larger sizes are adsorbed more preferably. The opposite tendency was observed by Seifi et al. [87]. The studies revealed that the functionalization of the surface of mineral adsorbents by surfactants can improve the efficiency of BTEX sorption from aqueous solution. Different loading levels of surfactant provide various sorption efficiency. An optimal loading level was 1.0-2.0 of CEC and higher loading level limited sorption efficiency.

The lowest values of sorption capacities were obtained for diatomite, zeolite $\mathrm{Y}$ and smectite modified by HDTMA. The most efficient adsorbents were montmorillonite modified with PEG and zeolite $Y$ modified with HDTMA. Most presented research revealed that sorption kinetics of organic compounds adsorption followed the mechanism of pseudo-second order model. The rate constant of pseudo-second kinetic, $k_{2}$, reflects the adsorption rate which was the lowest for diatomite. Indeed, in case of this mineral, the equilibrium state of adsorption was achieved after 10 days. Studied organo-mineral adsorbents exhibited faster rate of the organic compounds adsorption, confirmed by the experimental results and the calculated rate constants. In general, the adsorption was rapid in the first stage. The following stage was a slower adsorption process where the increase of the adsorption capacity became much slower than that of first stage, followed by the state of equilibrium in which the adsorption capacity remained at a constant level. The most efficient adsorbent in terms of the rate of the 
adsorption was HDTMA-smectite. The first rapid stage lasted about $10 \mathrm{~min}$ and the equilibrium state was achieved after $60 \mathrm{~min}$. Isotherm models used in several studies indicates the high applicability of Freundlich model that assumes the adsorption of physical nature onto heterogeneous surface.

The important issue is regeneration of the used adsorbents since they constitute a waste that can be hazardous for the environment. Results presented by Nourmoradi et al. [81] and Vidal et al. [57] show that it is possible to regenerate the used organo-mineral adsorbents by thermal treatment without significant loss of further sorption efficiency.

\subsection{Sorption of Volatile Petroleum Derivatives}

For the removal of volatile petroleum derivatives (including BTX), activated carbons, polymers or silica gels of very high surface area are generally used [83,89]. In recent years, natural and synthetic zeolites have also been considered as alternatives to these. Zeolites exhibit great thermal stability in contrast to polymers or carbons. They can therefore be applied instead, in particular conditions such as high temperatures or the risk of fire. Sorption capacities of different zeolites towards volatile organic compounds from gas streams are presented in Table 3. The investigations were carried out using a fixed-bed flow contractor [88-91] and/or TPD techniques (temperature programmed desorption) [92,93].

Table 3. Sorption capacities $\left(q_{e}\right)$ of selected adsorbents towards volatile organic compounds from gas streams.

\begin{tabular}{|c|c|c|c|c|c|c|c|}
\hline \multirow{2}{*}{ Sorbent } & \multicolumn{2}{|c|}{$S_{\text {BET }}\left(\mathrm{m}^{2} / \mathrm{g}\right)$} & \multirow{2}{*}{ Adsorbate } & \multirow{2}{*}{$T\left({ }^{\circ} \mathrm{C}\right)$} & \multicolumn{2}{|c|}{$q_{e}(\mathrm{mg} / \mathrm{g})$} & \multirow{2}{*}{ Source } \\
\hline & $623 \mathrm{~K}$ & $823 \mathrm{~K}$ & & & $623 \mathrm{~K}$ & $823 \mathrm{~K}$ & \\
\hline natural zeolite-NZ & 205 & 170 & toluene & 20 & 0.028 & 0.009 & [90] \\
\hline acid treated NZ & 434 & 369 & toluene & 20 & 0.131 & 0.104 & [90] \\
\hline ion exchanged NZ & 181 & 222 & toluene & 20 & 0.035 & 0.056 & [90] \\
\hline $\begin{array}{c}\text { double ion } \\
\text { exchanged NZ }\end{array}$ & 171 & 261 & toluene & 20 & 0.082 & 0.074 & [90] \\
\hline natural mordenite & \multicolumn{2}{|c|}{20} & $\begin{array}{l}\text { benzene } \\
\text { toluene } \\
p \text {-xylene }\end{array}$ & 20 & \multicolumn{2}{|c|}{$\begin{array}{l}1.9 \\
1.9\end{array}$} & [91] \\
\hline $\begin{array}{l}\text { acid-treated } \\
\text { mordenite }\end{array}$ & 12 & & $\begin{array}{l}\text { benzene } \\
\text { toluene } \\
p \text {-xylene }\end{array}$ & 20 & \multicolumn{2}{|c|}{$\begin{array}{l}21.9 \\
25.8 \\
11.4\end{array}$} & [91] \\
\hline MFI & 37 & & $\begin{array}{l}\text { acetone } \\
p \text {-xylene } \\
n \text {-hexane }\end{array}$ & 25 & \multicolumn{2}{|c|}{$\begin{array}{l}105.71 \\
135.88 \\
110.31\end{array}$} & [92] \\
\hline *BEA & 45 & & $\begin{array}{l}\text { acetone } \\
p \text {-xylene } \\
n \text {-hexane }\end{array}$ & 25 & \multicolumn{2}{|c|}{$\begin{array}{l}124.87 \\
124.21 \\
106.00\end{array}$} & [92] \\
\hline STT & 53 & & $\begin{array}{l}\text { acetone } \\
p \text {-xylene } \\
n \text {-hexane }\end{array}$ & 25 & \multicolumn{2}{|c|}{$\begin{array}{c}141.12 \\
102.98 \\
97.38 \\
\end{array}$} & [92] \\
\hline CHA & 80 & & $\begin{array}{l}\text { acetone } \\
p \text {-xylene } \\
n \text {-hexane }\end{array}$ & 25 & \multicolumn{2}{|c|}{5.808} & [92] \\
\hline faujasite Y HY901 & 5 & & $\begin{array}{l}\text { toluene } \\
\text { MEK }\end{array}$ & 25 & \multicolumn{2}{|c|}{$\begin{array}{l}1068.82 \\
757.155\end{array}$} & [93] \\
\hline faujasite X MS13X & 58 & & $\begin{array}{l}\text { toluene } \\
\text { MEK }\end{array}$ & 25 & \multicolumn{2}{|c|}{$\begin{array}{l}340.92 \\
778.79\end{array}$} & [93] \\
\hline
\end{tabular}


Table 3. Cont.

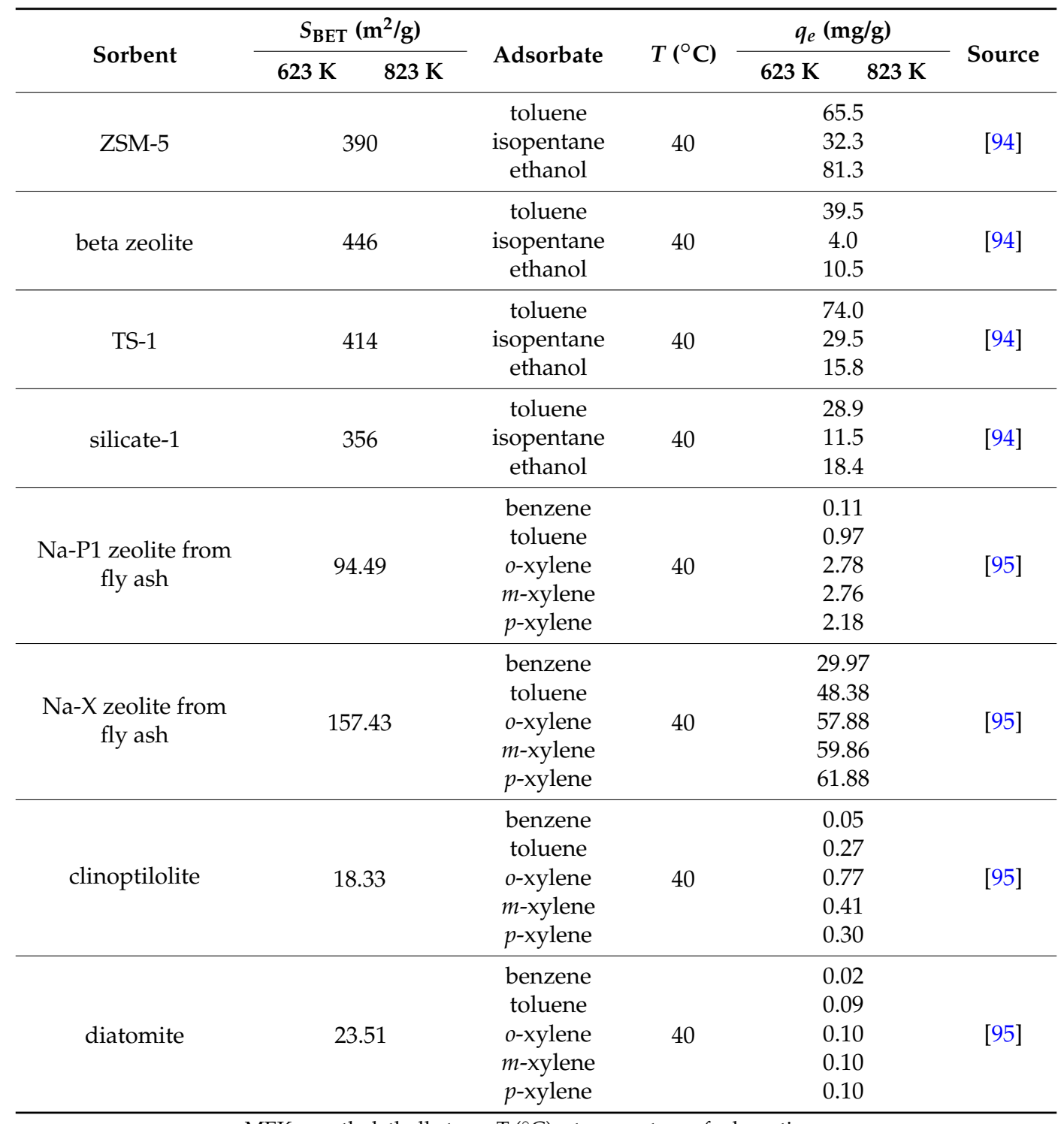

MEK-methylethylketone; $\mathrm{T}\left({ }^{\circ} \mathrm{C}\right)$-temperature of adsorption.

Alejandro et al. [90] investigated the sorption of toluene on natural zeolite from Chile (53\% clinoptilolite, $40 \%$ mordenite and $7 \%$ quartz) which was treated with use of hydrochloric acid and ammonium sulphate and then thermally activated at 623 and $823 \mathrm{~K}$ (activation was performed for chemically treated and untreated samples). The grain size was $0.3-0.425 \mathrm{~mm}$. The procedure of toluene adsorption-ozonation experiments was carried out in a fixed-bed flow contactor (ID $45 \mathrm{~mm}$ ) operating at room temperature $\left(20^{\circ} \mathrm{C}\right)$ and $101 \mathrm{kPa}$. The concentration of toluene was regulated by bubbling dry air into pure liquid toluene and diluted to a desired concentration by mixing with an air stream $(22.2 \mu \mathrm{mol} / \mathrm{L})$. The stream with toluene vapor of constant concentration was continuously supplied over the zeolite bed until saturation was achieved. Next, toluene was replaced by ozone. Toluene concentrations at the inlet and outlet streams were monitored on-line by gas chromatography (GC-FID). Sorption capacities in terms of toluene were 1.46 and $0.55 \mu \mathrm{mol} / \mathrm{m}^{2}$ for zeolite heated at 623 and $823 \mathrm{~K}$ respectively. The specific surface area $\left(S_{\mathrm{BET}}\right)$ of thermally treated zeolite was 205 and $170 \mathrm{~m}^{2} / \mathrm{g}$, and calculated sorption expressed in $\mathrm{mg} / \mathrm{g}$ was 0.028 and 0.009 respectively. Sorption efficiency increased after acid treatment to 3.27 and $3.07 \mu \mathrm{mol} / \mathrm{m}^{2}(0.131$ and $0.104 \mathrm{mg} / \mathrm{g})$, and after ion exchange to $2.07-5.22$ and $2.76-3.09 \mu \mathrm{mol} / \mathrm{m}^{2}(0.035-0.082$ and $0.056-0.074 \mathrm{mg} / \mathrm{g})$ respectively 
(higher values were obtained after a double ion exchange process). After these thermal and chemical modifications, both the specific surface area $\left(S_{\mathrm{BET}}\right)$ of zeolite and its surface character have changed. Higher temperatures caused a decrease in $S_{\mathrm{BET}}$ of untreated and acid treated samples, and an increase in the case of zeolite after ion exchange. The surface character was responsible for toluene sorption capacity, and for the efficiency of the oxidative regeneration processes.

Another zeolite which has been used for volatile organic compounds BTX (benzene, toluene and $p$-xylene) sorption is mordenite (natural and after acid treatment) investigated by Valdés et al. [91]. The fraction chosen for the experiments was $0.3-0.425 \mathrm{~mm}$. The sorption experiment was performed as described by Alejandro et al. [90] using fixed-bed flow contactor (4mm ID) at $20^{\circ} \mathrm{C}$ and $101 \mathrm{kPa}$. Pre-adsorbed benzene, toluene or $p$-xylene was then desorbed using a temperature programmed desorption (TPD) procedure by heating the sample up to $550{ }^{\circ} \mathrm{C}$ (heating rate of $10{ }^{\circ} \mathrm{C} / \mathrm{min}$ ). The influence of moisture was also studied by mixing a humidified stream $(40 \%$ of relative humidity $\mathrm{RH}$ ) with the BTX stream at the inlet. It was found that acid treatment increased $\mathrm{S}_{\mathrm{BET}}$ significantly, from 20 to $128 \mathrm{~m}^{2} / \mathrm{g}$. Simultaneously, sorption efficiency towards benzene, toluene and $p$-xylene increased from 3.6, 1.9 and $1.9 \mathrm{mg} / \mathrm{g}$ to $21.9,25.8$ and $11.4 \mathrm{mg} / \mathrm{g}$ respectively. In the presence of moisture, the values of adsorption capacities of raw mordenite and after acid treatment towards benzene, toluene and $p$-xylene decreased by $21 \%, 29 \%, 32 \%$; and by $68 \%, 65 \%, 41 \%$, respectively.

Cosseron et al. [92] used several types of zeosils (pure silica zeolites; chabazite (CHA-structure type), SSZ-23 (STT-structure type) with cage-like structure, silicalite-1 (MFI-structure type) and beta (*BEA-structure type) with channel structure) for the adsorption of $n$-hexane, acetone and $p$-xylene. The measurements were performed under flow using a thermogravimetric balance Setaram TG92 instrument (at relative pressure $p / p_{0}=0.5$ at $25{ }^{\circ} \mathrm{C}$ ). Sorption capacities of $p$-xylene were in the range $0.04-1.28 \mathrm{mmol} / \mathrm{g}(4.25-135.88 \mathrm{mg} / \mathrm{g})$ depending on the zeolite structure.

Kim and Ahn [93] investigated several types of commercial synthetic zeolites from a group of mordenite, faujasite $\mathrm{Y}$ and faujasite $\mathrm{X}$ in terms of the sorption of volatile organic compounds (benzene, toluene, $o$-xylene, $m$-xylene, $p$-xylene, methanol, ethanol, isopropanol, and methylethylketone (MEK)) using a continuous flow system under atmospheric pressure. The temperature of adsorption was $25^{\circ} \mathrm{C}$. Vapor concentration was monitored with a gas chromatograph equipped with thermal conductivity detector (GC-TCD). Desorption experiments were performed after sorption by microwave heating $\left(5^{\circ} \mathrm{C} / \mathrm{min}\right)$ to 300 or $500^{\circ} \mathrm{C}$. The highest sorption capacities were noted for the faujasite types of zeolites, abbreviated as HY901 and MS13X. In the case of toluene, SCs were 1.07 and $0.34 \mathrm{~g} / \mathrm{g}$ respectively, whereas for mordenites SCs were below $0.10 \mathrm{~g} / \mathrm{g}$. The BET surface areas of HY901 and MS13X were similar to that of two other faujasites $Y$ however, their sorption capacities towards tested volatile organic compounds were much higher. It indicates that the sorption capacity of volatile organic compounds by zeolites does not depend on the $S_{\text {BET }}$.

Serrano et al. [94] used the TPD method to determine the sorption capacities towards toluene, isopentane, and ethanol of synthetic zeolites synthesized from chemical reagents; sorption capacities were determined to be in the range $25-75 \mathrm{mg} / \mathrm{g}$. The zeolites synthesized by Serrano exhibited high purity and specific surface area.

In our paper [95] we examined diatomite, Ukrainian clinoptilolite and two types of synthetic zeolites from fly ash (Na-P1 and Na-X) in terms of the sorption of benzene, toluene and xylenes from a gas stream using the TPD technique. Adsorption of hydrocarbons was carried out at $45^{\circ} \mathrm{C}$. The effects of hydrocarbon dosing were analyzed at the reactor outlet using the mass spectrometer equipped with an electron multiplier detector. After the complete saturation of the samples the TPD was performed with a heating rate of $10^{\circ} \mathrm{C} / \mathrm{min}$ and a constant helium flow of $45 \mathrm{~cm}^{3} / \mathrm{min}$ in the temperature range $45-800{ }^{\circ} \mathrm{C}$. Sorption capacities in terms of BTX for these materials were within the ranges $0.02-0.10$, $0.05-0.77,0.11-2.78$ and $29.97-61.88 \mathrm{mg} / \mathrm{g}$ respectively. $\mathrm{Na}-\mathrm{X}$ showed significantly higher sorption than Na-P1 and other minerals used in the study.

In the papers presented above, the authors have generally considered the influence of the textural and chemical properties of mineral adsorbents on the sorption of volatile organic compounds 
(including petroleum industry derivatives). Most studies concern adsorbents of the zeolite type. It can be postulated that in the sorption of a compound such as BTX, the most important feature is the pore structure of zeolites; better sorption properties were observed for zeolites with ink-bottle pores [92] and zeolites of faujasite structure (HY901 and MS13X, Na-X) [93,95]. Their extremely high sorption performance with respect to the investigated molecules is a result of their relatively high surface area, with a large contribution of the micropores and their specific structure. These kinds of zeolites behave like molecular sieves towards volatile organic compounds and molecules of similar size due to "windows" of $7.4 \AA$ diameter in the micropore structure of faujasite. It can be noticed that sorption capacities of mordenites were higher for benzene, probably because the molecules of benzene are smaller than xylenes and can penetrate into the channels of mordenite easier. Strong relationship between the crystal structure and adsorption capacity was proved by Kim and Ahn [93] and Bandura et al. [95].

\section{Conclusions}

This paper presents an overview of recent research papers concerning mineral materials, synthetic zeolites and organo-minerals used as adsorbents for petroleum pollutants present in waters, air and spilled on land, occurring as oils, petroleum industry derivatives and volatile compounds. For the practical application, these adsorbents should meet the following criteria: availability, ease of acquisition, costs, good textural parameters, appropriate grain size.

The literature data indicate that minerals with high mesoporosity are recommended for the removal of land-based petroleum spills; the most promising results have been obtained for diatomites, sepiolite and zeolites from fly ash. Additionally, the synthesis of zeolites from fly ash allows to utilize wastes generated in heat and power plants, thus reducing their negative impact on the environment.

The mechanism of oil substances adsorption on porous surface of minerals includes capillary action connected with filling the available pores and oily layer (film) formation on the external surface and around the adsorbent grains. Oil substances cannot penetrate into narrow micropores of mineral adsorbents. The dependency between oil viscosity and density has been also observed. Generally, more viscous and dense oils were adsorbed in higher amounts than light oils by the same adsorbent material.

In the case of applications for water media, one of the main selection criteria is the hydrophobicity of the sorbent surface, which can be achieved from the modification of a mineral with surfactants such as quaternary ammonium salts. These modifications seem to be promising in the case of clay minerals and zeolites. Organo-clays and organo-zeolites exhibit higher sorption performance towards organic compounds in water media than the raw materials. Most studies revealed that the mechanism of organic compounds adsorption from aqueous solution by minerals and organo-minerlas can be described well by Freundlich isotherm which indicates physical sorption on heterogeneous surface. In terms of kinetics, it followed pseudo-second order model in most presented research.

Investigation on the organic pollutants adsorption from gases, the best results were obtained for synthetic zeolites from the group of faujasite. An important factor in those cases was high surface area and the contribution and structure of micropores. Faujasites can act as molecular sieves, selective for volatile organic compounds.

Mineral sorbents have a number of features relevant to their usage in the removal of petroleum compounds. The most favorable are: availability, environmental friendliness, low cost of acquisition and the possibility of recycling. Therefore, it is fully justified to obtain new types of inorganic and/or organic-inorganic structures dedicated to petroleum substances adsorption, with well-defined textural and chemical properties. It is also necessary to identify new / potential directions of spent adsorbents utilization since they constitute waste hazardous for the environment. Apart from being recovered by calcination, they can also be used as additives in the production of building materials such as lightweight aggregates.

Acknowledgments: We acknowledge the financial support from NCBiR within the Project GEKON 2/O2/266818/1/2015 
Author Contributions: Lidia Bandura was responsible for the article conception, collected literature, wrote the manuscript. Wojciech Franus participated in conception, literature collection, writing article parts, substantive comments and care. Agnieszka Woszuk was responsible for data collection on volatile compounds sorption. Dorota Kołodyńska was responsible for data collection on BTEX sorption from water.

Conflicts of Interest: The authors declare no conflict of interest.

\section{References}

1. Paulauskienė, T.; Jucikè, I.; Juščenko, N.; Baziukè, D. The use of natural sorbents for spilled crude oil and diesel cleanup from the water surface. Water Air Soil Pollut. 2014, 225, 1959-1971. [CrossRef]

2. Zhang, J.; Fan, S.; Yang, J.; Du, X.; Li, F.; Hou, H. Petroleum contamination of soil and water, and their effects on vegetables by statistically analyzing entire data set. Sci. Total Environ. 2014, 476-477, 258-265. [CrossRef] [PubMed]

3. Moro, A.M.; Brucker, N.; Charão, M.F.; Sauer, E.; Freitas, F.; Durgante, J.; Bubols, G.; Campanharo, S.; Linden, R.; Souza, A.P.; et al. Early hematological and immunological alterations in gasoline station attendants exposed to benzene. Environ. Res. 2015, 137, 349-356. [CrossRef] [PubMed]

4. Aguilera, F.; Méndez, J.; Pásaro, E.; Laffon, B. Review on the effects of exposure to spilled oils on human health. J. Appl. Toxicol. 2010, 30, 291-301. [CrossRef] [PubMed]

5. Alonso-Alvarez, C.; Pérez, C.; Velando, A. Effects of acute exposure to heavy fuel oil from the Prestige spill on a seabird. Aquat. Toxicol. 2007, 84, 103-110. [CrossRef] [PubMed]

6. Camacho, M.; Boada, L.D.; Orós, J.; Calabuig, P.; Zumbado, M.; Luzardo, O.P. Comparative study of polycyclic aromatic hydrocarbons (PAHs) in plasma of Eastern Atlantic juvenile and adult nesting loggerhead sea turtles (Caretta caretta). Mar. Pollut. Bull. 2012, 64, 1974-1980. [CrossRef] [PubMed]

7. Zytner, R.G. Sorption of benzene, toluene, ethylbenzene and xylenes to various media. J. Hazard. Mater. 1994, 38, 113-126. [CrossRef]

8. Półka, M.; Kukfisz, B.; Wysocki, P.; Polakovic, P.; Kvarcak, M. Efficiency analysis of the sorbents used to adsorb the vapors of petroleum products during rescue and firefighting actions. Przem. Chem. 2015, 1, 109-113.

9. Chagas-Spinelli, A.C.O.; Kato, M.T.; de Lima, E.S.; Gavazza, S. Bioremediation of a tropical clay soil contaminated with diesel oil. J. Environ. Manag. 2012, 113, 510-516. [CrossRef] [PubMed]

10. Broje, V.; Keller, A.A. Improved mechanical oil spill recovery using an optimized geometry for the skimmer surface. Environ. Sci. Technol. 2006, 40, 7914-7918. [CrossRef] [PubMed]

11. Saikia, R.R.; Deka, S. Removal of hydrocarbon from refinery tank bottom sludge employing microbial culture. Environ. Sci. Pollut. Res. Int. 2013, 20, 9026-9033. [CrossRef] [PubMed]

12. Ji, F.; Li, C.; Dong, X.; Li, Y.; Wang, D. Separation of oil from oily wastewater by sorption and coalescence technique using ethanol grafted polyacrylonitrile. J. Hazard. Mater. 2009, 164, 1346-1351. [CrossRef] [PubMed]

13. Nikolajsen, K.; Kiwi-Minsker, L.; Renken, A. Structured fixed-bed adsorber based on zeolite/sintered metal fibre for low concentration VOC removal. Chem. Eng. Res. Des. 2006, 84, 562-568. [CrossRef]

14. Mathur, A.K.; Majumder, C.B.; Chatterjee, S. Combined removal of BTEX in air stream by using mixture of sugar cane bagasse, compost and GAC as biofilter media. J. Hazard. Mater. 2007, 148, 64-74. [CrossRef] [PubMed]

15. Khan, F.I.; Ghoshal, A.K. Removal of volatile organic compounds from polluted air. J. Loss Prev. Process Ind. 2000, 13, 527-545. [CrossRef]

16. Al-Majed, A.A.; Adebayo, A.R.; Hossain, M.E. A sustainable approach to controlling oil spills. J. Environ. Manag. 2012, 113, 213-227. [CrossRef] [PubMed]

17. Fritt-Rasmussen, J.; Brandvik, P.J. Measuring ignitability for in situ burning of oil spills weathered under Arctic conditions: From laboratory studies to large-scale field experiments. Mar. Pollut. Bull. 2011, 62, 1780-1785. [CrossRef] [PubMed]

18. Boglaienko, D.; Tansel, B. Partitioning of fresh crude oil between floating, dispersed and sediment phases: Effect of exposure order to dispersant and granular materials. J. Environ. Manag. 2016, 175, 40-45. [CrossRef] [PubMed] 
19. Zhao, X.; Liu, W.; Fu, J.; Cai, Z.; O'Reilly, S.E.; Zhao, D. Dispersion, sorption and photodegradation of petroleum hydrocarbons in dispersant-seawater-sediment systems. Mar. Pollut. Bull. 2016, 109, 526-538. [CrossRef] [PubMed]

20. Cheng, M.; Zeng, G.; Huang, D.; Yang, C.; Lai, C.; Zhang, C.; Liu, Y. Advantages and challenges of Tween 80 surfactant-enhanced technologies for the remediation of soils contaminated with hydrophobic organic compounds. Chem. Eng. J. 2017, 314, 98-113. [CrossRef]

21. Sundaravadivelu, D.; Suidan, M.T.; Venosa, A.D.; Rosales, P.I. Characterization of solidifiers used for oil spill remediation. Chemosphere 2016, 144, 1490-1497. [CrossRef] [PubMed]

22. Sundaravadivelu, D.; Suidan, M.T.; Venosa, A.D. Parametric study to determine the effect of temperature on oil solidifier performance and the development of a new empirical correlation for predicting effectiveness. Mar. Pollut. Bull. 2015, 95, 297-304. [CrossRef] [PubMed]

23. Rosales, P.I.; Suidan, M.T.; Venosa, A.D. A laboratory screening study on the use of solidifiers as a response tool to remove crude oil slicks on seawater. Chemosphere 2010, 80, 389-395. [CrossRef] [PubMed]

24. Fingas, M. Review of Solidifiers: An Update 2013; Prince Williams Sound Regional Citizens' Advisory Council: Edmonton, AB, Canada, 2013.

25. Chebbi, R. Profile of oil spill confined with floating boom. Chem. Eng. Sci. 2009, 64, 467-473. [CrossRef]

26. Agnello, A.C.; Bagard, M.; van Hullebusch, E.D.; Esposito, G.; Huguenot, D. Comparative bioremediation of heavy metals and petroleum hydrocarbons co-contaminated soil by natural attenuation, phytoremediation, bioaugmentation and bioaugmentation-assisted phytoremediation. Sci. Total Environ. 2016, 563-564, 693-703. [CrossRef] [PubMed]

27. Chen, M.; Xu, P.; Zeng, G.; Yang, C.; Huang, D.; Zhang, J. Bioremediation of soils contaminated with polycyclic aromatic hydrocarbons, petroleum, pesticides, chlorophenols and heavy metals by composting: Applications, microbes and future research needs. Biotechnol. Adv. 2015, 33, 745-755. [CrossRef] [PubMed]

28. Wu, M.; Dick, W.A.; Li, W.; Wang, X.; Yang, Q.; Wang, T.; Xu, L.; Zhang, M.; Chen, L. Bioaugmentation and biostimulation of hydrocarbon degradation and the microbial community in a petroleum-contaminated soil. Int. Biodeterior. Biodegrad. 2016, 107, 158-164. [CrossRef]

29. Atlas, R.M.; Hazen, T.C. Oil biodegradation and bioremediation: A tale of the two worst spills in U.S. history. Environ. Sci. Technol. 2011, 45, 6709-6715. [CrossRef] [PubMed]

30. Srinivasan, A.; Viraraghavan, T. Oil removal from water using biomaterials. Bioresour. Technol. 2010, 101, 6594-6600. [CrossRef] [PubMed]

31. Szarlip, P.; Stelmach, W.; Jaromin-Gleń, K.; Bieganowski, A.; Brzezińska, M.; Trembaczowski, A.; Hałas, S.; Łagód, G. Comparison of the dynamics of natural biodegradation of petrol and diesel oil in soil. Desalin. Water Treat. 2014, 52, 3690-3697. [CrossRef]

32. Adebajo, M.O.; Frost, R.L.; Kloprogge, J.T.; Carmody, O.; Kokot, S. Porous materials for oil spill cleanup: A review of synthesis and absorbing properties. J. Porous Mater. 2003, 10, 159-170. [CrossRef]

33. Tic, W. Characteristics of adsorbents used to remove petroleum contaminants from soil and wastewater. Przem. Chem. 2015, 1, 79-84.

34. Wahi, R.; Chuah, L.A.; Choong, T.S.Y.; Ngaini, Z.; Nourouzi, M.M. Oil removal from aqueous state by natural fibrous sorbent: An overview. Sep. Purif. Technol. 2013, 113, 51-63. [CrossRef]

35. Uzunov, I.; Uzunova, S.; Angelova, D.; Gigova, A. Effects of the pyrolysis process on the oil sorption capacity of rice husk. J. Anal. Appl. Pyrolysis 2012, 98, 166-176. [CrossRef]

36. Kenes, K.; Yerdos, O.; Zulkhair, M.; Yerlan, D. Study on the effectiveness of thermally treated rice husks for petroleum adsorption. J. Non-Cryst. Solids 2012, 358, 2964-2969. [CrossRef]

37. Abdullah, M.A.; Rahmah, A.U.; Man, Z. Physicochemical and sorption characteristics of Malaysian Ceiba pentandra (L.) Gaertn. as a natural oil sorbent. J. Hazard. Mater. 2010, 177, 683-691. [CrossRef] [PubMed]

38. Li, J.; Luo, M.; Zhao, C.J.; Li, C.Y.; Wang, W.; Zu, Y.G.; Fu, Y.J. Oil removal from water with yellow horn shell residues treated by ionic liquid. Bioresour. Technol. 2013, 128, 673-678. [CrossRef] [PubMed]

39. Lin, J.; Shang, Y.; Ding, B.; Yang, J.; Yu, J.; Al-Deyab, S.S. Nanoporous polystyrene fibers for oil spill cleanup. Mar. Pollut. Bull. 2012, 64, 347-352. [CrossRef] [PubMed]

40. Li, H.; Liu, L.; Yang, F. Hydrophobic modification of polyurethane foam for oil spill cleanup. Mar. Pollut. Bull. 2012, 64, 1648-1653. [CrossRef] [PubMed] 
41. Wu, D.; Fang, L.; Qin, Y.; Wu, W.; Mao, C.; Zhu, H. Oil sorbents with high sorption capacity, oil/water selectivity and reusability for oil spill cleanup. Mar. Pollut. Bull. 2014, 84, 263-267. [CrossRef] [PubMed]

42. Pichór, W.; Mozgawa, W.; Król, M.; Adamczyk, A. Synthesis of the zeolites on the lightweight aluminosilicate fillers. Mater. Res. Bull. 2014, 49, 210-215. [CrossRef]

43. Franus, M.; Wdowin, M.; Bandura, L.; Franus, W. Removal of environmental pollutions using zeolites from fly ash: A review. Fresenius Environ. Bull. 2015, 24, 854-866.

44. Wdowin, M.; Franus, M.; Panek, R.; Badura, L.; Franus, W. The conversion technology of fly ash into zeolites. Clean Technol. Environ. Policy 2014, 16, 1217-1223. [CrossRef]

45. Wdowin, M. Raw kaolin as a potential material for the synthesis of a-Type Zeolite. Gospodarka Surowcami Mineralnymi Miner. Resour. Manag. 2015, 31, 45-57.

46. Belviso, C. EMT-type zeolite synthesized from obsidian. Microporous Mesoporous Mater. 2016, 226, 325-330. [CrossRef]

47. Burham, N.; Sayed, M. Adsorption behavior of $\mathrm{Cd}^{2+}$ and $\mathrm{Zn}^{2+}$ onto natural Egyptian bentonitic clay. Minerals 2016, 6, 129. [CrossRef]

48. Oueslati, W.; Ammar, M.; Chorfi, N. Quantitative XRD analysis of the structural changes of Ba-exchanged montmorillonite: Effect of an in situ hydrous perturbation. Minerals 2015, 5, 507-526. [CrossRef]

49. Aivalioti, M.; Vamvasakis, I.; Gidarakos, E. BTEX and MTBE adsorption onto raw and thermally modified diatomite. J. Hazard. Mater. 2010, 178, 136-143. [CrossRef] [PubMed]

50. Bastani, D.; Safekordi, A.A.; Alihosseini, A.; Taghikhani, V. Study of oil sorption by expanded perlite at 298.15 K. Sep. Purif. Technol. 2006, 52, 295-300. [CrossRef]

51. Teas, C.; Kalligeros, S.; Zanikos, F.; Stournas, S.; Lois, E.; Anastopoulos, G. Investigation of the effectiveness of absorbent materials in oil spills clean up. Desalination 2001, 140, 259-264. [CrossRef]

52. Carmody, O.; Frost, R.; Xi, Y.; Kokot, S. Adsorption of hydrocarbons on organo-clays-implications for oil spill remediation. J. Colloid Interface Sci. 2007, 305, 17-24. [CrossRef] [PubMed]

53. Simpson, J.A.; Bowman, R.S. Nonequilibrium sorption and transport of volatile petroleum hydrocarbons in surfactant-modified zeolite. J. Contam. Hydrol. 2009, 108, 1-11. [CrossRef] [PubMed]

54. Wang, D.; McLaughlin, E.; Pfeffer, R.; Lin, Y.S. Adsorption of oils from pure liquid and oil-water emulsion on hydrophobic silica aerogels. Sep. Purif. Technol. 2012, 99, 28-35. [CrossRef]

55. Emam, E.A. Modified activated carbon and bentonite used to adsorb petroleum hydrocarbons emulsified in aqueous solution. Am. J. Environ. Prot. 2013, 2, 161-169. [CrossRef]

56. Sakthivel, T.; Reid, D.L.; Goldstein, I.; Hench, L.; Seal, S. Hydrophobic high surface area zeolites derived from fly ash for oil spill remediation. Environ. Sci. Technol. 2013, 47, 5843-5850. [CrossRef] [PubMed]

57. Vidal, C.B.; Raulino, G.S.C.; Barros, A.L.; Lima, A.C.A.; Ribeiro, J.P.; Pires, M.J.R.; Nascimento, R.F. BTEX removal from aqueous solutions by HDTMA-modified Y zeolite. J. Environ. Manag. 2012, 112, 178-185. [CrossRef] [PubMed]

58. Szala, B.; Bajda, T.; Matusik, J.; Zięba, K.; Kijak, B. BTX sorption on Na-P1 organo-zeolite as a process controlled by the amount of adsorbed HDTMA. Microporous Mesoporous Mater. 2015, 202, 115-123. [CrossRef]

59. Muir, B.; Matusik, J.; Bajda, T. New insights into alkylammonium-functionalized clinoptilolite and Na-P1 zeolite: Structural and textural features. Appl. Surf. Sci. 2016, 361, 242-250. [CrossRef]

60. Muir, B.; Bajda, T. Organically modified zeolites in petroleum compounds spill cleanup-Production, efficiency, utilization. Fuel Process. Technol. 2016, 149, 153-162. [CrossRef]

61. Moazed, H.; Viraraghavan, T. Removal of oil from water by bentonite organoclay. Pract. Period. Hazard. Toxic Radioact. Waste Manag. 2005, 9, 130-134. [CrossRef]

62. Alther, G.R. Organically modified clay removes oil from water. Waste Manag. 1995, 15, 623-628. [CrossRef]

63. Mowla, D.; Karimi, G.; Salehi, K. Modeling of the adsorption breakthrough behaviors of oil from salty waters in a fixed bed of commercial organoclay/sand mixture. Chem. Eng. J. 2013, 218, 116-125. [CrossRef]

64. Sarkar, B.; Megharaj, M.; Shanmuganathan, D.; Naidu, R. Toxicity of organoclays to microbial processes and earthworm survival in soils. J. Hazard. Mater. 2013, 261, 793-800. [CrossRef] [PubMed]

65. Michel, M.M. Sorpcja oleju na złożach mineralnych. The sorption of oil on the mineral beds. Sci. Rev. Eng. Environ. Sci. 2005, 1, 95-102. (In Polish)

66. Bandura, L.; Franus, M.; Panek, R.; Woszuk, A.; Franus, W. Characterization of zeolites and their use as adsorbents of petroleum substances. Przem. Chem. 2015, 94, 323-327. 
67. Standard Test Method for Sorbent Performance of Adsorbents; ASTM F726-99; American Society for Testing and Materials: West Conshohocken, PA, USA, 1999.

68. Zhao, M.Q.; Huang, J.Q.; Zhang, Q.; Luo, W.L.; Wei, F. Improvement of oil adsorption performance by a sponge-like natural vermiculite-carbon nanotube hybrid. Appl. Clay Sci. 2011, 53, 1-7. [CrossRef]

69. Ankowski, A. Wykorzystanie zeolitów z popiołów lotnych w sorpcji substancji ropopochodnych w warunkach rzeczywistych. In Proceedings of the Debata o Przyszłości Energetyki, Wysowa Zdrój, Poland, 4-7 May 2010. (In Polish)

70. Zadaka-Amir, D.; Bleiman, N.; Mishael, Y.G. Sepiolite as an effective natural porous adsorbent for surface oil-spill. Microporous Mesoporous Mater. 2013, 169, 153-159. [CrossRef]

71. Bandura, L.; Franus, M.; Józefaciuk, G.; Franus, W. Synthetic zeolites from fly ash as effective mineral sorbents for land-based petroleum spills cleanup. Fuel 2015, 147, 100-107. [CrossRef]

72. Franus, M.; Jozefaciuk, G.; Bandura, L.; Lamorski, K.; Hajnos, M.; Franus, W. Modification of lightweight aggregates' microstructure by used motor oil addition. Materials 2016, 9, 845. [CrossRef]

73. Franus, W.; Jozefaciuk, G.; Bandura, L.; Franus, M. Use of spent zeolite sorbents for the preparation of lightweight aggregates differing in microstructure. Minerals 2017, 7, 25. [CrossRef]

74. Boglaienko, D.; Tansel, B. Instantaneous stabilization of floating oils by surface application of natural granular materials (beach sand and limestone). Mar. Pollut. Bull. 2015, 91, 107-112. [CrossRef] [PubMed]

75. Boglaienko, D.; Tansel, B. Encapsulation of light hydrophobic liquids with fine quartz sand: Property based characterization and stability in aqueous media with different salinities. Chem. Eng. Sci. 2016, 145, 90-96. [CrossRef]

76. Boglaienko, D.; Tansel, B.; Sukop, M.C. Granular encapsulation of light hydrophobic liquids (LHL) in LHL-salt water systems: Particle induced densification with quartz sand. Chemosphere 2016, 144, 1358-1364. [CrossRef] [PubMed]

77. Boglaienko, D.; Tansel, B. Gravity induced densification of floating crude oil by granular materials: Effect of particle size and surface morphology. Sci. Total Environ. 2016, 556, 146-153. [CrossRef] [PubMed]

78. Carmody, O.; Frost, R.; Xi, Y.; Kokot, S. Surface characterisation of selected sorbent materials for common hydrocarbon fuels. Surf. Sci. 2007, 601, 2066-2076. [CrossRef]

79. Carmody, O.; Frost, R.; Xi, Y.; Kokot, S. Selected adsorbent materials for oil-spill cleanup: A thermoanalytical study. J. Therm. Anal. Calorim. 2008, 91, 809-816. [CrossRef]

80. Carvalho, M.N.; da Motta, M.; Benachour, M.; Sales, D.C.S.; Abreu, C.A.M. Evaluation of BTEX and phenol removal from aqueous solution by multi-solute adsorption onto smectite organoclay. J. Hazard. Mater. 2012, 239-240, 95-101. [CrossRef] [PubMed]

81. Nourmoradi, H.; Nikaeen, M.; Khiadani, M. Removal of benzene, toluene, ethylbenzene and xylene (BTEX) from aqueous solutions by montmorillonite modified with nonionic surfactant: Equilibrium, kinetic and thermodynamic study. Chem. Eng. J. 2012, 191, 341-348. [CrossRef]

82. Aivalioti, M.; Pothoulaki, D.; Papoulias, P.; Gidarakos, E. Removal of BTEX, MTBE and TAME from aqueous solutions by adsorption onto raw and thermally treated lignite. J. Hazard. Mater. 2012, 207-208, 136-146. [CrossRef] [PubMed]

83. Standeker, S.; Novak, Z.; Knez, Z. Removal of BTEX vapours from waste gas streams using silica aerogels of different hydrophobicity. J. Hazard. Mater. 2009, 165, 1114-1118. [CrossRef] [PubMed]

84. Sharmasarkar, S.; Jaynes, W.F.; Vance, G.F. BTEX sorption by montmorillonite organo-clays: TMPA, ADAM, HDTMA. Water Air Soil Pollut. 2000, 119, 257-273. [CrossRef]

85. Simantiraki, F.; Aivalioti, M.; Gidarakos, E. Laboratory study on the remediation of BTEX contaminated groundwater using compost and Greek natural zeolite. In Proceedings of the CRETE 2012 3rd International Conference on Industrial and Hazardous Waste Management, Chania, Greece, 12-14 September 2012; pp. 1-8.

86. Torabian, A.; Kazemian, H.; Seifi, L.; Bidhendi, G.N.; Azimi, A.A.; Ghadiri, S.K. Removal of petroleum aromatic hydrocarbons by surfactant-modified natural zeolite: The effect of surfactant. Clean Soil Air Water 2010, 38, 77-83. [CrossRef]

87. Seifi, L.; Torabian, A.; Kazemian, H.; Bidhendi, G.N.; Azimi, A.A.; Farhadi, F.; Nazmara, S. Kinetic study of BTEX removal using granulated surfactant-modified natural zeolites nanoparticles. Water Air Soil Pollut. 2011, 219, 443-457. [CrossRef]

88. Ho, Y.; McKay, G. Pseudo-second order model for sorption processes. Process Biochem. 1999, 34, 451-465. [CrossRef] 
89. Long, C.; Li, Y.; Yu, W.; Li, A. Removal of benzene and methyl ethyl ketone vapor: Comparison of hypercrosslinked polymeric adsorbent with activated carbon. J. Hazard. Mater. 2012, 203-204, 251-256. [CrossRef] [PubMed]

90. Alejandro, S.; Valdés, H.; Manéro, M.H.; Zaror, C.A. Oxidative regeneration of toluene-saturated natural zeolite by gaseous ozone: the influence of zeolite chemical surface characteristics. J. Hazard. Mater. 2014, 274, 212-220. [CrossRef] [PubMed]

91. Valdés, H.; Solar, V.A.; Cabrera, E.H.; Veloso, A.F.; Zaror, C.A. Control of released volatile organic compounds from industrial facilities using natural and acid-treated mordenites: The role of acidic surface sites on the adsorption mechanism. Chem. Eng. J. 2014, 244, 117-127. [CrossRef]

92. Cosseron, A.F.; Daou, T.J.; Tzanis, L.; Nouali, H.; Deroche, I.; Coasne, B.; Tchamber, V. Adsorption of volatile organic compounds in pure silica CHA, BEA, MFI and STT-type zeolites. Microporous Mesoporous Mater. 2013, 173, 147-154. [CrossRef]

93. Kim, K.J.; Ahn, H.G. The effect of pore structure of zeolite on the adsorption of VOCs and their desorption properties by microwave heating. Microporous Mesoporous Mater. 2012, 152, 78-83. [CrossRef]

94. Serrano, D.P.; Calleja, G.; Botas, J.A.; Gutierrez, F.J. Characterization of adsorptive and hydrophobic properties of silicalite-1, ZSM-5, TS-1 and Beta zeolites by TPD techniques. Sep. Purif. Technol. 2007, 54, 1-9. [CrossRef]

95. Bandura, L.; Panek, R.; Rotko, M.; Franus, W. Synthetic zeolites from fly ash for an effective trapping of BTX in gas stream. Microporous Mesoporous Mater. 2016, 223, 1-9. [CrossRef]

(C) 2017 by the authors. Licensee MDPI, Basel, Switzerland. This article is an open access article distributed under the terms and conditions of the Creative Commons Attribution (CC BY) license (http:/ / creativecommons.org/licenses/by/4.0/). 